УДК 903.25 (477.7)

DOI: https://doi.org/10.33782/eminak2021.1(33).508

\title{
Декоративні елементи вбрання населення Степового Побужжя
}

\author{
Любов Клочко \\ Національний музей історії України (Київ, Україна) \\ e-mail: liubaklochko@ukr.net \\ ORCID: https://orcid.org/0000-0003-3496-6340
}

Пам'яті колеги та друга Юрія Гребенникова

У статті йдеться про особливості іконографії та семантики образів, зображення яких вміщено на золотих ювелірних виробах - прикрасах костюмів соціальної верхівки суспільства. Розглянуто знакові функції головного убору модія, а також знімних прикрас у вбранні скіфів.

Ключові слова: міфічні образи, семантика знімних прикрас, скіфські головні убори

Археологічні дослідження на території Побужжя особливо інтенсивно проводили у 70-80 роки XX ст. Вивчено десятки курганів різних часів і все завдяки праці співробітників Новобудівної Інгульської експедиції під керівництвом О.Г. Шапошникової. Розкопки відбувалися, переважно, у степах Миколаївської області - басейнах Південного Бугу та Інгульця. Знайдені у курганах археологічні пам'ятки стали об'єктами вивчення фахівців з доби бронзи та раннього заліза.

У 2008 р. вийшла монографія Ю. Гребенникова, в якій він проаналізував артефакти, знайдені у 300 похованнях, здійснених у IX-III ст. до н.е. Поховальний обряд, супровідне начиння, прикраси - елементи костюмів, вузда, озброєння - узагальнення цих матеріалів дозволило Ю. Гребенникову викласти деякі спостереження щодо специфіки регіону, який знаходився поблизу Ольвії, а також соціальної структури суспільства ${ }^{1}$. Автор виділив чотири групи пам'яток за такими параметрами, як висота кургану та глибина могили. Ці утворення (групи) є прошарками населення, яке було неоднорідним через сімейно-родові зв'язки й особливості господарювання. Дві групи - прості общинники, ще дві - населення належало до більш заможної частини суспільства.

Ю. Гребенников наголошував, що територія Степового Побужжя складала впродовж V-III ст. до н.е. окрему адміністративну область, управління якою здійснювали представники молодшої гілки царського роду. Це відобразили матеріали, зокрема декоративні елементи, що походять з деяких курганів².

Особливо привертають увагу знахідки в кургані № 21 (поховання 2) поблизу с. Кам'янка (Очаківський р-н, Миколаївська обл.). Висота кургану 2 м, під насипом було три могили: поховання чоловіка (пограбоване), дівчинки - підлітка (10-13 років), а також жінки (середнього віку). Знахідки у цій могилі та безпосередньо при небіжчиці виділяють її з числа захоронень середнього і, навіть, вищого шару

\footnotetext{
1 Гребенников Ю.С. Киммерийцы и скифы Степного Побужья (IX-III вв. до н.э.). Николаев, 2008. $192 \mathrm{c.}$

2 Гребенніков Ю. Скіфська модель «адміністративного» устрою Степового Побужжя в V - IV ст. до н.е. // Емінак. 2008. № 3. С. 25-29.
} 
населення регіону. Йдеться про те, що у північно-західній полі кургану, в досить просторій поховальній камері $(3,7 \times 2,4 \times 1,5$ м) поклали жінку, вбрання якої вирізняють золоті оздоби: аплікації на головних уборах, сережки, намисто з золотими підвісками, персні. У могилі знайшли також два прясельця, залізне шило, бронзове дзеркало. Крім того, біля стінки камери знайшли кістки жертовної тварини, а також амфору․․ Увесь поховальний інвентар містить інформацію для визначення соціальної ролі жінки та її місця у спільноті.

Отже, як завжди, почнемо з голови. У результаті вивчення історії костюмів науковці зробили деякі узагальнення щодо об’єктів, які належать до категорії «головні убори». Виділені такі види: платкові, стрічкові та шапки. Археологічні матеріали (пам'ятки образотворчого мистецтва та декоративні елементи) свідчать, що скіф'янки, за певних умов, поєднували усі види головних уборів ${ }^{4}$. У костюмі жінки, знахідки з поховання якої ми зараз розглядаємо, було 2 головних убори: налобна стрічка та шапка. В усякому разі, саме про такі убори свідчать золоті аплікації. Налобну пов'язку, чи стрічку, прикрашала пластина головного убору, так звана метопіда - золота смужка $(2,5 \times 33$ см), яку прикріпляли крізь отвори (зроблені зверху і з боків) до текстильної основи. Поле метопіди розділене на дві частини, між якими - тоненький пружок. Над ним рельєфний візерунок: від центральної пальметки обабіч зображені плавні тоненькі лінії (у вигляді синусоїди), від яких відходять пагінці з квітами та різьбленими листочками. Цей орнамент знизу підкреслює плетінка з напівовів.

Схожа метопіда була серед декоративних елементів убору скіф'янки, поховання якої дослідили у кургані № 22 (п. 2) поблизу с. Вільна Україна (Херсонської обл. $)^{5}$.

Стрічкові убори різних груп та типів (налобні пов'язки, вінки, діадеми), а також наголовні покривала, мабуть, є найдавнішими за походженням. Простота форми сприяли, з одного боку, їх поширенню в убранні багатьох народів, а 3 іншого - спонукали до застосування різноманітних декоративних засобів. Обидва види належать до уборів, які мають глибокі корені: стрічки та покривала носили за доби неоліту - бронзи у Середземномор'ї, деяких регіонах Центральної та Північної Європи. Етнолокальну та соціальну специфіку відбивали матеріали виробу, розміри, оздоблення тощо.

Ще один вид головних уборів - шапки. Саме вони акцентували жіночий репрезентативний костюм. Шапки складають дві групи: тверді (жорсткі) та м'які. Їх характеристики «закодовані» у формах, які визнані стійкими типологічними ознаками. Святкові шапки - «жорсткі» або «тверді убори» циліндричного, конусоподібного, або напівсферичного абрису. Для їх виготовлення використовували спеціальний крій, щільні матеріали - повсть, шкіру - робили каркаси із гнучких гілок 6.

\footnotetext{
${ }^{3}$ Клочко Л.С., Гребенников Ю.С. Скифский калаф IV в. до н.э. // Материалы по хронологии археологических памятников Украины. Киев: Наук. думка, 1982. С. 86.

4 Клочко Л.С. Новые материалы к реконструкции скифских головных уборов // Древности Степной Скифии. Киев: Наукова думка, 1982. С. 124-127.

5 Лесков О.М. Скарби курганів Херсонщини. Київ: Мистецтво, 1974. С. 80-92.

6 Клочко Л.С., Васіна 3.О. Реконструкція головних уборів за декоративними елементами із поховань скіф'янок (версії загальної класифікації) // Музейні читання: Матеріали наукової конференції Музею історичних коштовностей України «Ювелірне мистецтво - погляд крізь віки». Київ, 1517 листопада 2010 р. Київ: Феникс, 2011. С. 32-43.
} 
Специфіку декоративних елементів головних уборів скіф'янок вивчали відомі дослідники М. Ростовцев і Г. Боровка7. Зокрема, за спостереженням Г. Боровки деякі прикраси несуть ознаки форми: прямокутні пластинки, довгі стрічки: також прямокутні, а, окрім того, дугоподібні пластинки, обідки з підвісками - підкреслювали циліндричну поверхню і тому одержали назву формотворчих. Вони стали об'єктами досліджень вчених різних спеціальностей: археологів, істориків костюмів, мистецтвознавців. Результати роботи - реконструкції уборів, які отримали назви: полос, «скіфський» і «грецький» калаф, модій, а також - «тіара»8.

У похованні жінки в кургані № 21 поблизу с. Кам'янка зафіксовано металеві аплікації, які прикрашали поверхню шапки циліндричної форми. Деталі оформлення убору - золоті та срібні пластинки, обідки з підвісками - лежали у шарі темно-вишневого тліну (можливо, повсті). Золоті аплікації - 8 екземплярів: досить великі чотирикінцеві накладки з тонкого золотого листа, зберегли абрис трохи увігнутих стінок убору. На пластинках - рельєфні міфічні та фітоморфні образи. Щоб підкреслити їх силуети, вирізано фон, тобто пластинки ажурні. Склад образів не випадає з кола мотивів, які вміщували на уборах, реконструйованих за знахідками у похованнях скіф'янок. Але іконографія міфічних і рослинних зображень $\epsilon$ унікальною. Фітоморфні мотиви: на 4 пластинках у формі трапеції, нижня основа якої менша ніж верхня. На трьох аплікаціях представлено пальметку, обабіч якої - пагони, які закінчуються квітами (рис. 1.1).

Композиція вміщена в рамку, яка має вигляд тоненьких пружків зверху та знизу, а бокові сторони рамки утворені з двох смужок, між якими відтиснуто орнамент: спрощений варіант «мікенської хвилі». У деяких екземплярах частина облямівки обрізана, і це призвело до змін у конфігурації та розмірах пластинок. Дві майже однакові, оскільки зліва і справа збереглись сторони облямування. Розміри однієї з пластинок: зверху - 62 мм, знизу - 55 мм; а другої: зверху 60 мм, знизу - 54 мм. Розміри ще однієї: зверху - 57 мм, а знизу - 51 мм. Висота всіх аплікацій майже однакова: 40-42 мм. В основу зображення пальметки покладено мотив крина (пагона) - символу відроджуваних сил природи. Як відомо, саме $з$ крину «виростають» композиції з рослинною тематикою.

Ще одна пластинка, ймовірно, вирізана з довгої смуги. Про це свідчить, насамперед, фрагмент візерунка: його основою була хвиляста лінія (синусоїда) з пагінцями аканфа і квітами (розміри: знизу - 86 мм, зверху - 95 мм, висота - 38 мм) (рис. 1.2).

Особливу цікавість викликають аплікації, на яких вміщено образи міфічних істот. У літературі за ними закріплена назва грифон, хоча виникають заперечення щодо терміну. Зображення в рамках, схожих на ті, якими облямовані пальметки, тобто зверху та знизу - тоненькі пружки, бокові сторони - смужки «мікенської хвилі».

На двох пластинах зображення грифонів невизначеного виду. Вони представ-

\footnotetext{
7 Ростовцев М.И., Степанов П.К. Эллино-скифский головной убор // Известия археологической комиссии. 1918. Вып. 63. С. 69, 100; Боровка Г.Н. Женские головные уборы Чертомлыцкого кургана // Известия Российской академии истории материальной культуры. 1921. Т. 1. С. 169.

8 Клочко Л.С., Васіна 3.О. Реконструкція головних уборів...; Клочко Л.С. Типы декоративных элементов в оформлении головных уборов скифянок // Tyragetia. 2013. s.n., vol. VII [XXII], nr. 1. S. 1928; Мирошина T.В. Некоторые типы скифских женских головных уборов IV-III вв. до н.э. // Советская археология. 1981. № 4. С. 46-69.
} 
лені у профільному ракурсі: обернені вліво і вправо, стоять, піднявши передню лапу - ліву або праву, як це притаманно різним істотам у геральдичній композиції. Загальними рисами у трактуванні образів $є$ тулуб з підтягнутим животом, міцні лапи хижака з породи котячих, великі серпоподібні розгорнуті крила, на яких традиційно позначено пір'я: короткими рисками знизу, довгими дугами зверху. Але кожне зображення має власні характеристики. Грифон обернений вліво, голова виконана у гротескному стилі: з невиразними рисами, без видових ознак, але показана відкрита паща. Кругле око підкреслене бровою у вигляді дуги, ріг у формі трикутника нахилений вперед. Від підборіддя майже до лапи звисає борода. На довгій шиї - гребінь, позначений короткими рельєфними насічками. Розміри пластинки: знизу - 50 мм, зверху - 55 мм, висота - 42-45 мм (рис. 1.3а).

Інший вигляд має грифон обернений вправо. Голова трохи піднята. На ній ріг, загнутий вперед, а велике вухо - назад. Передня частина морди невиразна, але видно закриту пащу. Борода ледь приєднана до підборіддя. Впадають в око ще деякі деталі: коротка шия, на якій відстовбурчується трикутник. Обидва крила у верхній частині так сильно загнуті, що праве торкається вуха. На правому стегні - спіральний завиток. Розміри пластинки: знизу - 60 мм, зверху - 69 мм, висота - 42 мм (рис. 1.4а).

Ще дві ажурні пластини представляють унікальний образ грифона з головою козла. На одній пластині він показаний оберненим вправо. Силует нагадує вухастого бородатого грифона, описаного раніше: тулуб з підтягнутим животом, обабіч - великі крила із загнутими заокругленими кінцями. Обидва крила вкриті лускатим візерунком - імітацією пір'я: знизу короткі рельєфні смужки, а зверху імітація довгих пір'їн. Виразно показані міцні лапи хижака з породи котячих. Ліва лапа піднята. На правому стегні відтиснута тонка хвиляста лінія. Але найбільше у цьому образі міфічної істоти привертає увагу ії козлина голова. Вона виконана із застосуванням прийомів стилізації: акцентовані витягнута морда з овальним оком, під яким округле заглиблення, обвислий ніс, довга борода та дугоподібні роги. Їх утворюють дві тоненькі рельєфні лінії, між якими поперечні валики. Лівий ріг повторює контури голови та шиї. Кінчик рогу - під крилом. Правий ріг починається від скроні і закінчується на грудях. На голові між рогами - імітація шерстяного покрову. Розміри пластинки: знизу - 60 мм; зверху - 64 мм, висота 42 см. Зліва залишилася бічна сторона рамки: між двома пружками варіант мікенської хвилі (рис. 1.3б).

Ще одна ажурна пластинка також із зображенням грифона з козлиною головою, оберненого вліво. За силуетом тулуба всі грифони, зображені на пластинках, схожі. Це ж можна сказати і про абрис крил. На аплікації з козлиноголовим грифоном, оберненим вліво, ліве крило закручене на кінці і торкається голови, а праве пошкоджене численними дрібними отворами: такі є на всіх пластинках для прикріплення їх до декорованої поверхні. Зображення втиснуте у рамку шириною - 40 мм, висотою - 42 мм (рис. 4б).

Манера трактування образів на всіх пластинках характерна у творчості торевтів Північного Причорномор'я IV ст. до н.е. Силуети вирізані за контурами, відтвореними на одній матриці: кострубаті тіла грифонів, положення крил і ніг, але майстер застосовував різні художні засоби для певної індивідуалізації. Особливо виразними є голови козлів: тонкі роги вкриті рубчиками - алюзія на реальну ознаку дикого козла. Образ цієї тварини був поширеним в архаїчному мистецтві скіфів у Пів- 
нічному Причорномор'ї, причому, видова ознака, тобто, роги подані зі значною мірою стилізації: рельєфний валик огинає голову та шию9. У пам'ятках IV ст. до н.е. найчастіше бачимо зображення, очевидно, свійських тварин. Наприклад, скульптурні підвіски до сережок із Мордвинівського кургану (Херсонська обл.), фігури кіз на пекторалі із Товстої Могили, дорослі особини в орнаментах на золотих стрічках - прикрасах жіночого головного убору із кургану Чортомлик (Дніпропетровська обл.), козенят - аплікації з кургану № 1 (поховання 2) поблизу с. Володимирівка (Херсонська обл.) ${ }^{10}$. Образ козла за уявленнями греків пов'язаний з культом Діоніса - одного з богів життєдайних сил природи. Можливо, в уявленнях скіфів козел посів певне місце як символ плодючості, уособлення світу земного.

Образи грифонів, як й інших монстрів, вже не раз розглядали науковці. А.Р.Канторович, створюючи класифікацію зображень міфічних істот, зазначив, що головною ознакою грифона є поєднання елементів хижого звіра і птаха 11. Ю. Полідович також вважає, що тільки фантастична істота з ознаками лева та хижого птаха $є$ грифоном/грифом ${ }^{12}$. Але у науковій літературі здавна різноманітні поліморфні істоти називають грифонами. Семантика образу залежить від того, які ще зображення складають композицію чи просто поєднані у декорі якогось предмета. За припущенням А. Канторовича синкретичні образи - явище, яке народилось з індо-іранських легенд про інфернальні зони, населені фантастичними істотами ${ }^{13}$. Іконографія монстрів була створена під впливом передньоазіатського й еллінського мистецтва, але образи, мабуть, відбивають уявлення скіфів про потойбічні світи: верхній і нижній. Обидва таємничі, а вхід до них охороняють чудовиська, які $є$ контамінацією різних істот.

Серед декоративних елементів головного убору знайдено 8 круглих срібних 3 позолотою пластинок (d - 27 мм). На них відтиснута сцена «шматування», персонажі якої лев і копитна тварина (лань?). Зображення дещо спотворені через корозію срібла. Але у загальних рисах сюжет можна «прочитати». Обидві тварини показані у профільному ракурсі. Зображення облямоване пружком, на якому мініатюрні напівсферичні опуклини. На описаних круглих пластинках пробито дірочки (як і на інших аплікаціях). Тіло лева пластично вигнуте за обрисами кола. Голова обернена в фас: акцентована пишна грива, виділені округлі вуха, видовжений ніс. Лев уп'явся у стегно копитної тварини, на її шиї лежить ліва передня лапа хижака. Другий персонаж - лань (?) зображена також відповідно до вимог форми площини (кола). За невеликими фрагментами можна уявити лань 3 підігнутим під животом ногами та піднесеною головою (рис. 1,5).

Пластинки з подібними сюжетами знайшли у курганах Північного Причорномор'я. Найближча аналогія: аплікації з південної гробниці № 2 у кургані Гайма-

\footnotetext{
9 Виногродська Я.О. До інтерпретації зображень на платівках скіфського архаїчного головного убору. //Музейні читання: Матеріали наук. конф. МІКУ. Київ, грудень 1999 р. Київ, 2000. С. 21-22, рис. 1.

10 Клочко Л.С. Зооморфні образи в декорі скіфських головних уборів V-IV ст. до н.е. // Музейні читання: Матеріали наук. конф. МІКУ, Київ, грудень 1999 р. Київ, 2000. С. 27-28, табл. II.

11 Канторович А.Р. Образы синкретических существ в восточноевропейском скифском зверином стиле: классификация, типология, хронология, иконографическая динамика // Исторические исследования. 2015. № 3. С. 120.

12 Полидович Ю.Б. Образы фантастических животных в искусстве народов скифского мира // Донецький археологічний збірник. 2015. № 19. С. 101.

13 Ibid. C. 118.
} 
нова могила (Запорізька обл.). На думку дослідників, на пластинках зображено шматування барана левом ${ }^{14}$. С.В. Полін навів приклади пластинок зі схожим сюжетом та їх різну інтерпретацію, але, мабуть, змістовно вони однорідні, відбиваючи ідею жертвоприношення 15.

Серед прикрас головного убору зафіксовані так звані обідки з підвісками (ширина - 8 мм): 4 фрагменти, загальна довжина 650 мм. Оздоби зроблені у вигляді вузенької смужки з рельєфним візерунком, верхній край трохи загнутий. Нижче напаяні кільця, а між ними - відтиснуті ови. До кілець через ще одне колечко приєднані гладенькі амфороподібні підвіски (рис. 1,6). Обідки з підвісками є важливими деталями оформлення головного убору, за якими можна уявити його форму. Аналіз інших елементів, їх фіксація in situ, вивчення пам'яток, на яких представлені зображення скіф'янок в ошатному вбранні - усе це є підставами для реконструкції головного убору.

Як зазначено вище, ажурні пластинки з міфічними образами та фітоморфними мотивами прикрашали циліндричний убір. Визначення «циліндричний» не зовсім точне, адже в дійсності форми шапок складніші та не завжди відповідають строгим рамкам геометричної фігури, тобто циліндра. Але цей термін - циліндричний - дозволяє знайти закономірності у створенні уборів, зрозуміти принципи їх модифікації.

Пам’ятки торевтики з курганів Скіфії містять інформацію про убори з цієї групи. Так, на голові богині - центрального персонажа багатофігурної композиції на пластині з кургану поблизу с. Сахнівка (Черкаська обл.), бачимо полос - високу циліндричну шапку з пласкою верхівкою. Характерна риса убору - невелика різниця між нижнім і верхнім діаметрами 16.

У літературі недостатньо чітко розроблена термінологія щодо давніх костюмів, зокрема, головних уборів. Найчастіше, фахівці, описуючи головні убори, які носили жінки на території Скіфії, залучають термін калаф. Убір поширений в античному світі як корона божеств життєдайних сил природиㄱ. Він походить від кошика для плодів, квітів, вовни, сиру. За формою нагадує зрізаний конус, перевернутий широкою основою догори. Пам'ятки грецької культури надають можливість уявити убір, що нагадує кошик з вузьким дном ${ }^{18}$. Головна особливість калафа у тому, що він не є шапкою: це корона, тобто у неї відкрита маківка.

Археологічні матеріали та пам'ятки образотворчого мистецтва свідчать про те, що деякі головні убори за силуетом нагадують калаф: невисокі, розширюються догори, але вони відрізняються від «класичного» убору пропорціями - нижня основа дорівнює окружності голови. Такий убір реконструйовано за знахідками у кургані Велика Близниця (поблизу с. Стеблієвка на Таманському півострові) ${ }^{19}$. Його форму - зрізаний конус - чітко відображають золоті аплікації (30 примірників). Розмір нижньої основи убору - 620 мм, а окружність верхнього - 820 мм. Прикраси

\footnotetext{
14 Бидзиля В.И., Полин С.В. Скифский царский курган Гайманова Могила. Киев: Издат. Дом «Скиф», 2012. С. 486, кат. № 300.

15 Ibidem.

16 Музей історичних коштовностей України: Альбом / Л.С. Клочко, О.П. Підвисоцька, О.В. Старченко й ін. Київ: Мистецтво, 2004. С. 53, кат. № 22.

17 Irmscher J. (Hg.). Lexikon der Antike. Leipzig: VEB Bibliographisches Institut, 1979. S. 266.

18 Артамонов М.И. Сокровища скифских курганов. Ленинград, Артия, 1966. Табл. 179, 296, 300, $267,308$.

19 Ibid. Табл. 284-285.
} 
- пластинки з антропоморфними та міфічними образами - були прикріплені на бічній поверхні убору. Можливо, до таких шапочок більше підходить назва модій 20. I хоча цей термін поки що не набув поширення: частіше убір називають «скіфським калафом», але саме модій - за всіма ознаками відповідає описаній формі.

Отже, відтворюючи вигляд модія (скіфського калафа) за знахідками у кургані № 21 поблизу с. Кам’янка, беремо до уваги, що розміщення пластинок-аплікацій на поверхні убору здійснювали за певними законами побудови композицій. Ці закономірності проявилися у створенні орнаментальних схем, об'єднанні окремих персонажів у сюжеті.

Образи грифонів часто представлені у геральдичних сценах, а зображення пальметки є змістовним і композиційним центром в орнаментах. Можна припустити, що пластинки були прикріплені на уборі таким чином: у центрі - пальметка, справа та зліва: грифони - орлиноголовий і з головою козла) один проти другого, і ще одна пальметка. Довга пластина з рослинним візерунком прикрашала убір на потилиці, адже у похованні не було ніяких слідів покривала, а воно, як свідчать реконструкції головних уборів, часто закривало неприкрашену частину шапки. Обідки з підвісками були закріплені над ажурними пластинами. Завершенням оздоблення убору є круглі пластинки, прикріплені на опуклому денці21 (рис. 1,7). Аналогічні убори - модії, реконструйовані за знахідками у курганах Тетянина Могила (Дніпропетровська обл.), № 22 (поховання 1) поблизу с. Вільна Україна (Херсонська обл.)22.

Ажурні прикраси на уборах естетично привабливі завдяки фону, на якому було вміщено декор. Саме червоний колір - різні його відтінки - викликали в уявленнях давніх людей асоціації з кров'ю, вогнем, сонцем, в яких можна «прочитати» звернення до різних аспектів культу плодючості. Висота відтвореного модія становить близько 7-8 см.

Аналіз декору парадного убору був би неповним, якщо не висловити припущення про виробництво деяких категорій прикрас. Своєрідність іконографії міфічних істот - так званих грифонів, можливо пов'язана з творчими пошуками скіфів. Вони використали деякі технічні прийоми роботи із золотими пластинами, на яких витискували зображення, а потім вирізали ділянки за контуром образу, щоб створити ажурний витвір. Можна припустити, що у скіфських майстрів був певний досвід роботи з повстю та шкірою якраз із виготовлення ажурних візерунків. Ці навички вони могли застосувати у роботі з золотом ${ }^{23}$. В еллінських майстернях виконані круглі пластинки зі сценою шматування, обідки з підвісками.

Як уже сказано, у вбранні модій складав ансамбль з налобною стрічкою, а також - з сережками. Їх могли носити на стрічці, або у мочці вушка. Йдеться про пару кільцеподібних прикрас з підвісками (рис. 2). Кільце з круглого у перетині дроту, кінці тупо обрізані та заходять один за одний. Підвіски - фігурні намистини, виготовлені з двох з'єднаних між собою рельєфних антропоморфних масок.

\footnotetext{
20 Слово «модій» має кілька значень: стародавні греки так називали міру об'єму рідини та сипких тіл, й окрім того, циліндричний жертовний посуд.

${ }^{21}$ Клочко Л.С., Гребенников Ю.С. Скифский калаф... С. 91.

22 Клочко Л.С., Іваненко А.С. Полос, калаф, модій (реконструкція за ажурними прикрасами зі скіфських поховань // Пам'ятки центру пам'яткознавства. 2017. Вип. 32. С. 41-52.

23 Полосьмак Н., Баркова Л. Костюм и текстиль пазырыкцев Алтая (IV-III вв до н.э.). Новосибирск: Инфолио, 2005. С. 44.
} 
Зображення обличчя схематичне, узагальнено подано і зачіску. Знизу та з двох боків, у місцях з'єднання половинок підвіски, за допомогою дротяних кілечок прикріплені привіски у вигляді дисків з тонкого золотого листа. Зверху до підвіски припаяні циліндрик з рифленою поверхнею та рубчасте вушко, крізь яке намистину надіто на кільце 24 . Схожі прикраси знайдені у кургані 17 (поховання 2) поблизу с. Золота Балка (Херсонська обл.) 25.

Ще один елемент костюмного комплексу - намисто з намистин зі склоподібної маси та золотих амфороподібних підвісок. 3 категорії наручних прикрас скіф'янка мала персні (п'ять на лівій руці й один - на правій). Вироби вирізані із золотої пластини: овальний щиток з двома дужками із загостреними кінцями, що заходять один за одний. На щиток кожного персня напаяно пластинку, на якій вміщена рельєфна сцена «шматування»: лев насів на барана. Зображення облямованою тоненькою рифленою дротинкою26.

Отже, костюмний комплекс скіф'янки включає майже всі категорії прикрас: у наборі нема тільки браслетів. Вбрання має статусний характер - $є$ знаком належності власниці до верхівки у своїй соціальній групі. Як було зазначено раніше, Ю. Гребенников вважав, що цей курган $є$ усипальницею представників адміністративної верхівки регіону ${ }^{27}$.

Декоративні елементи утворюють своєрідне сакральне коло, в якому зібрані образи: міфічні (грифони), фітоморфні (пальмета), антропоморфні (підвіска у вигляді голови людини), а також сюжет «шматування» (лев і лань, лев і баран). Всі вони є символами життєдайних сил природи та відбивають культ Великої Богині. Форма головного убору, його оздоблення - все це, можливо, свідчить про те, що жінка була жрицею цього божества (рис. 3).

У поховальному інвентарі небіжчиці $є$ категорія предметів, які підкреслюють сакральну роль скіф'янки у соціумі. Насамперед, йдеться про дзеркало 28. У даному випадку воно належить до рідкісного середземноморського типу, тобто було дорогим. Річ глибоко символічна: атрибут богині Аргімпаси (С. Бессонова) ${ }^{29}$, знак шлюбного обряду (Д. Раєвський) ${ }^{30}$, а також - портал для проходження до потойбіччя (іншого світу) (А. Вертієнко) ${ }^{31}$. Вказані функції відбивають різні змістовні акценти, пов'язані зі статусом власниці. Можна уявити такий «сценарій»: небіжчиця - жриця богині Аргімпаси. Між нею і «царем», похованим у цьому ж кургані, відбувається містичний шлюб, після чого жриця проводить небіжчика через портал - дзеркало у задзеркалля, тобто, до іншого світу.

Привертає увагу ще один артефакт з могили небіжчиці - прясельце. Такі деталі жіночого знаряддя для прядіння - веретена - знаходять у похованнях жінок, а зрідка й чоловіків, і вважають знаками захисту від злих сил. Знаряддя праці,

\footnotetext{
24 Шапошникова О.Г. Отчет о работе Ингульской археологической экспедиции за 1978 г. // Науковий архів Інститут археології НАН України. Ф. експ. 1978/11. С. 81, 85-86, табл. LI,1; LII,6.

25 Полин С.В. Скифский Золотобалковский курганный могильник V-IV вв. до н.э. на Херсонщине. Киев, 2014. С. 154, кат. 132.

26 Гребенников Ю.С. Киммерийцы и скифы... С. 93.

27 Гребенников Ю.С. Скіфська модель «адміністративного» устрою... С. 28.

28 Ibidem.

29 Бессонова С.С. Религиозные представления скифов. Киев: Наукова думка, 1983. С. 102-103.

30 Раєвский Д.С. Очерки идеологии скифо-сакских племен. Москва: Наука, 1977. С. 98-100.

31 Вертиенко Г.В. Зображення скіфської танатологічної міфологеми на сахнівській пластині // Східний світ. 2010. № 3. С. 62.
} 
пов'язані з одержанням нитки, можливо, мають глибинний зміст: відбивають уявлення про «нитку життя», властиві багатьом народам. Прядіння і ткацтво вважали дарунками богів і тому всі дії з прядивом (сировиною для ниток), далі готовою продукцією, виготовленням тканини - належать до сфери магічної. Найбільш яскраво це донесли образи грецької міфології32. Знаряддя для прядіння - прясельця, веретена, можливо, позначають статус жінки: вона тримає нитку життя, тобто зосереджує у своїх руках всі життєві сили членів роду чи сім'ї.

Нам важко уявити всі ритуали під час поховання: якісь дійства відбувались перед входом у камеру, а щось робили безпосередньо у могилі. Напевне, був певний порядок розміщення речей, адже всі вони набували іншого змісту при захороненні: знаряддя праці, посуд тощо. Домінантним для визначення послідовності в обрядах, як уже сказано раніше, було вбрання, сакральний зміст якого підкреслював золотий декор.

Ю.С. Гребенников виділяв ще один курган як такий, що був споруджений над могилами небіжчиків з числа представників верхівки регіону - Степового Побужжя ${ }^{33}$. Йдеться про курган № 9 поблизу с. Піски (Миколаївської обл.). Розміри кургану - 3,9 м, під його насипом були облаштовані 2 могили: центральна та бокова. На дослідженні бокового поховання археологи зосередили основну увагу, оскільки центральне було пограбоване у давнину. Отже, захоронення здійснено на глибині 6 м. Небіжчик - юнак 15-16 років був одягнений у парадний костюм: куртку, оздоблену золотими пластинками, підперезану поясом із золотим декором. До штанів, нижче колін, були прикріплені поножі з листового срібла. Особливий статус небіжчика підкреслюють золота гривна та срібний браслет. Крім того, у наборі супровідних речей було озброєння: однолезовий меч з руків'ям, плакованим золотом, два дротики, горит; посуд - масивний срібний з позолотою лутерій, срібна сітула, два кубки, бронзовий казан, амфори й червоноглиняна мисочка; до статусних речей належить нагайка зі срібним руків'ям.

Золоті аплікації, зафіксовані у похованні in situ, стали важливим джерелом для реконструкції верхнього наплічного одягу 34 . Зіставлення розміщення пластинок на кістяку небіжчика з пам'ятками образотворчого мистецтва, дозволило відтворити розпашний одяг - куртку, на рукавах та на спинці якої були прикріплені пластинки (75 екз., розміри 40×35 мм) із зображенням міфічної істоти, так званого грифона, хоча особливості зображення вимагають більш точного означення образу: найкраще відповідає назва дракон ${ }^{35}$. Стилізація образу виконана майстерно. Дракон поданий у профільному ракурсі: обернений вліво, його фігура скомпонована у прямокутній рамці, що має вигляд витого шнура (рис. 4). Рельєфні відбитки на пластинках виконані з використанням різних штампів, але «прочитати» зображення важко. Голова невиразна (хижака?), на міцній шиї, трохи піднята. Майстер підкреслив деякі характерні риси монстра: велике око, відкрита паща, під нижньою щелепою - короткі борозенки, які позначають бороду. На маківці голови - ріг, від якого вздовж шиї тоненьким рубчиком показано гребінь.

\footnotetext{
32 Яковенко Е.В. Про скіфські веретена // Золото степу. Археологія України. Шлезвіг, 1991. С. 112.

33 Гребенников Ю.С. Киммерийцы и скифы... С. 77.

34 Клочко Л.С. Верхній плечовий одяг скіфів // Археологія. 1984. Вип. 47. С. 57-68.

35 Полідович Ю.Б., Шаміна Т.П. Зображення скіфського дракона в колекції Музею історичних коштовностей України // Музейні читання: Матеріали наук. конф. МІКУ «Ювелірне мистецтво - погляд крізь віки». Київ, листопад 2015 р. Київ: Фенікс, 2015. С. 70, рис. 1,1.
} 
На деяких пластинках можна розгледіти лапи, схожі на пташині, з пазурами (?). Більшу частину поля займають крила та «хвіст» дракона. Ці деталі зображення вирізняє пластика, композиційна урівноваженість: серпоподібні крила, форма яких акцентована дугами - пір'їнами, частина тулуба, звужуючись від середини до кінця, спірально закручена. Науковці трактують цей синкретичний образ, як такий, що відбиває уявлення про поєднання різних світів: верхнього (крилата істота) та хтонічного (змієподібність). Наявність таких зображень у вбранні небіжчика, мабуть пов'язано ще з однією функцією золотого декору - захист від злих сил.

Ю. Гребенников вважав, що подібні образи монстрів можна ототожнювати 3 чудовиськом василіском. Це дає змогу припустити, що останній є знаком належності власника подібної емблеми до царського роду ${ }^{36}$.

Оздоби костюма юнака містять також і символи світу земного. Це прикраси пояса: прямокутні срібні з позолотою пластинки, краї яких виділені рамкою у вигляді перевитого шнура. Всередині облямівки - композиція з 4-х пальметок, розташованих симетрично щодо уявних діагоналей ${ }^{37}$.

До складу декоративних елементів убрання скіфа входять знімні прикраси золота гривна та спіралеподібний срібний браслет. Вироби - унікальні, привертають увагу художньою досконалістю.

Гривна напівспіральна з круглого у перетині дроту, відлита із золота (d 175 мм, довжина 622 мм). Витвір вирізняє оформлення закінчень: зображення голови фантастичного птаха у профільному ракурсі. Довгий плескатий дзьоб з маленьким круглим отвором (ніс?), борозенкою показано рот із зубами. Зображення голови геометризоване, умовно її можна назвати трапецієподібною. Тонкими пружками виділені всі риси образу: видовжене, наче примружене, око, всередині - опукла овальна зіниця, зліва від ока - заглиблення у вигляді кружальця (вушко?). На голові чітко виділено гребінь у вигляді зиґзага. Схожий зигзагоподібний візерунок, а також чотири пружки відділяють зображення голови від гладенького стрижня (рис. 5). Схожі за загальними характеристиками гривни, зроблені з кованого дроту, спіралеподібні (1,5 оберту), із зооморфними образами на кінцях знайдені: у курганах Чортомлик (північно-західна камера); Апан-Сарча (Крим); № 487 поблизу с. Капітанівка (Кіровоградська обл.); Гайманова Могила, поховання № 4 (Запорізька обл.); № 13, поховання № 3 поблизу с. Львове; № 13 з курганного могильника «Рядові Могили», поховання № 5 поблизу с. Золота Балка (Херсонська обл.) ${ }^{38}$.

Крім гривни, хлопчику поклали ще й багатовитковий браслет - 2,5 обороти зі срібного дроту. Виріб також вирізняє унікальне зооморфне оформлення. Воно збереглося на одному кінці, бо другий - обламаний у давнину. Отже, на одному кінці припаяний мініатюрний прямокутний брусок. Зверху на ньому вміщено стилізоване зображення голови тварини з великими вухами, виконане у техніці лиття за восковою моделлю. Прямокутне поле розділене заглибленою лінією майже пополам. Зліва - кілька борозенок, які зображують вуха у формі витягнутого трикутника. У правій половині на мініатюрному полі умовно показані очі

\footnotetext{
36 Гребенников Ю.С. Скіфська модель «адміністративного» устрою... С. 28.

37 Клочко Л.С. Верхній плечовий одяг... С. 65, рис. 8.

38 Петренко В.Г. Украшения Скифии VII-III вв. до н.э. Москва: Наука, 1978. С. 45, табл. 32, 1, 2, 4, 5; $33,2,3,4,5 ; 34,1)$.
} 
(видовжені заглибини), над поверхнею виступає великий ніс (рис. 6). Схожий за абрисом браслет знайдено у похованні жінки в кургані 13, поховання 2 групи БОФ (Дніпропетровська обл.) 39.

Гривна та браслет є не тільки взірцями стильової гармонії, ювелірної майстерності, але й відбивають символічний зміст, притаманний прикрасам цих категорій. Хлопець похований як дорослий воїн. Нашийний обруч - знак належності до верхівки спільноти, а образ грифона, ймовірно, емблема певного роду, засвідчує, що підліток пройшов обряд ініціацій, адже міфічну істоту сприймали як втілення сили, непереможності й інших чеснот, необхідних воїну (рис. 7).

Особливий статус небіжчика підкреслюють усі речі, що входили до поховального інвентарю: срібний кубок, зброя, вузда, обойма для точильного камінця тощо.

Розглянуті поховання мають значний інформаційний потенціал, завдяки тому, що не були пограбовані. Але й у зруйнованих могилах на землях Степового Побужжя знайдені декоративні вироби, які відбивають різні явища у бутті соціуму. Зокрема, специфіку художньої обробки металів. Костюми населення регіону за загальними характеристиками схожі на убрання скіфів, які жили в інших областях Скіфії. У могилах Побужжя знайдено різні категорії знімних прикрас: гривни - виділено золоту, більшість срібні, але є й бронзові; намисто - разки із намистин зі склоподібної маси; браслети - срібний спіралеподібний із зооморфним закінченням, а також - срібний пластинчастий, а більшість (10 екз.) - залізні; персні - найчастіше золоті, мають вигляд щитка з роз'ємними дужками ${ }^{40}$.

Найбільш поширеними прикрасами були сережки різного типу. Їх носили не тільки жінки, але й чоловіки та діти.

Як зазначено раніше, деякі ювелірні витвори виготовлені у греко-скіфському стилі майстрами якогось центру Північного Причорномор'я.

У V ст. до н.е. у середовищі еліти населення Скіфії увійшли в моду еллінські прикраси, декоративні елементи в оформлені головних уборів та одягу. Про це свідчать, зокрема, пам'ятки ювелірного мистецтва, в якому переважають грецькі мотиви. Вони, проникаючи у матеріальні та духовні сфери життя, одержували, ймовірно, нову інтерпретацію у свідомості населення Скіфії. Ці явища проявились у багатьох виробах, насамперед, у виготовленні сережок. Привертають увагу елементи убрання скіф’янки, поховання якої дослідили у кургані № 6, поховання № 1 поблизу с. Мар'янівка (Миколаївська обл.). В її костюмному комплексі були золоті сережки, намисто зі склоподібної маси, 4 срібні персні 41.

Сережки належать до типу кільцеподібних з підвісками (рис. 8). Останні фігурні: кожна зроблена з двох з'єднаних між собою штампованих пластин, вирізаних за контуром зображення анфас крилатого божества (h - 88 мм; d кільця 2621 мм; підвіска 29×33 мм). Жіночу фігуру вміщено серед пагонів в'юнкої рослини: такий вигляд має нижня частина постаті.

Як зазначають деякі дослідники, «існував генетичний зв'язок між зображеннями IV ст. до н.е. і персонажами легенд про походження скіфів» ${ }^{42}$. Йдеться про

\footnotetext{
39 Тереножкин А.И., Ильинская В.А., Черненко Е.В., Мозолевский Б.Н. Скифские курганы Никопольщины // Скифские древности. Київ: Наукова думка, 1973. С. 162, 10, рис. 43, 11.

40 Гребенников Ю. Киммерийцы и скифы... С. 91-92.

41 Шапошникова О.Г., Балушкин А.М., Гребенников Ю.С. и др. Отчет о работе Николаевской новостроечной экспедиции в 1986 г. // Науковий архів Інституту археології НАН України. 1986/18. C. 142

42 Бессонова С.С. Религиозные представления скифов. Киев, 1983. С. 93.
} 
«напівдіву - напівзмію», німфу Ору зі зміями замість ніг, діву зі зміїним тулубом. Мабуть, найбільш відомим був міф, в якому описано зустріч Геракла та істоти «дивної породи: до пояса це жінка, а далі - змія» (Геродот, IV, 52). Як бачимо, Геродот чітко змалював вигляд міфічної істоти. Її різноманітні трактування з'явились у творчості майстрів Північного Причорномор'я під впливом еллінських художніх традицій: жінка з крилами, рослинними візерунками замість ніг тощо. У літературі такі жіночі образи умовно називають «змієногою богинею», яку ототожнюють з Апі.

На пластинах до сережок з Мар'ївки зображено міфічний персонаж, в якому поєднано крилатий людський торс і фітоморфні мотиви. Таким чином відтворено тему - «діва, яка проростає», поширену у давньому мистецтві, як втілення ідеї відродження після смерті.

Аналогією «крилатому божеству», яке ми бачимо на пластинках мар'ївських сережок, є «діва, яка проростає», вигравірувана на гребні з кургану Гайманова Могила. Подібність образів не тільки у спільній схемі їх трактування, але й у деяких характерних деталях: крім рослинних візерунків, слід відмітити ще й пишні крила, якими обгорнуто постать божеств ${ }^{43}$. Але зображення на сережках вирізняє лаконізм нижньої частини: спіральні звиви гнучких рослин, позбавлені пишного листя, подібні до змій. Тобто, на підвісках до сережок показано синкретичну істоту, в якій поєднано образи крилатої «діви, що проростає», та змієногої богині. Цей образ уособлює культ плодючості. Його підкреслюють мініатюрні привіски у вигляді нерозкритого пуп'янка, прикріплені по периметру.

У верхній частині виробу відтиснуто рельєфні хвилясті лінії, які надають схожості кожній привісці зі справжнім бутоном. Аналогічні прикраси знайдено у похованнях скіф'янок у різних регіонах Скіфії: Придністров'ї (курган № 2, поховання № 3 поблизу с. Бутори Григоріопольського р-ну), на Херсонщині (курган № 8, поховання № 3 поблизу с. Тягинка Бериславського р-ну) ${ }^{44}$.

Привертає увагу набір знімних прикрас, який належав жінці, поховання якої дослідили у кургані № 29, поховання № 1 поблизу с. Пришиб (Миколаївської обл.): золоті сережки, намисто і п'ять перснів, крім того - один срібний 45 . Зупинимо погляд на сережках - кільцях з підвісками (h - 48 мм; d кільця 29 мм; h підвіски - 19 мм). Останні мають вигляд мушлі, виготовленої із двох з'єднаних між собою рельєфних пластин, вирізаних за контуром зображення мушлі-гребінця. По краю цієї фігурної деталі прикріплено сім маленьких привісок також у формі мушель. Вони, тобто привіски, прикрашені опуклими лініями, що чергуються 3 неглибокими борозенками - декор, притаманний природним мушлям, так званим «гребінцям» (рис. 9). Їх відтворення на пам'ятках мистецтва приваблює красивим малюнком контурів і віялоподібним візерунком на поверхні. У творчості античних майстрів зображення мушлі-гребінця використовували не тільки з декоративною метою, а й як один із символів Афродіти. Про це свідчить відтворен-

\footnotetext{
43 Савостина Е.А. «Змееногая богиня» - «прорастающая дева» (двухсторонний антропоморфный акротерий из Пантикапея) // Историко-археологический альманах. Армавир-Москва, 1996. Вып. 2. С. 76-83.

44 Петренко В.Г. Украшения Скифии VII-III ст. до н.э. Москва: Наука, 1978. Табл. 21, 7

45 Шапошникова О.Г., Балушкин О.М., Гребенников Ю.С. и др. Отчет о работе Николаевской экспедиции за 1984 год. Часть II. Работы Явкинского отряда // Науковий архів Інституту археології НАН України. 1984/9. С. 104, Табл. 69 (3).
} 
ня образу на лекіфі з Фанагорії: майстер змалював народження богині, показавши її оголену фігуру між двома стулками мушлі46. За уявленнями жителів Північного Причорномор'я - скіф'янок з аристократичних кіл - Афродіта була одним із божеств життєдайних сил природи. За часів еллінізму античні майстри робили флакончики у формі «гребінців». Використовували і справжні мушлі, можливо, як амулети ${ }^{47}$.

Як сказано вище, у костюмному комплексі з кургану поблизу с. Пришиб була також нашийна прикраса у вигляді ланцюжка з підвісками: вироби імітують на зовнішньому боці мушлю, а на звороті напаяна пластинка. Схожі прикраси знайдені у похованні Гайманової Могили (Південна гробниця № 4), Александрополь, Калькова Могила, Чортомлик III (курган 29, поховання 2) 48 . Як зазначив С. Полін, знахідка бронзового штампу у Пантикапеї, свідчить про можливий центр виготовлення підвісок-мушель ${ }^{49}$.

Цікаві обставини знахідок прикрас у кургані № 2, поховання № 1 поблизу с. Таборівка. У звіті читаємо: «У камері, пограбованій у давнину, знайдено скриньку, в якій лежали сережки-«кораблики», масивна кільцеподібна підвіска, намисто з кольорових скляних пірамідок, золотого та срібного бісеру, золотих, керамічних і скляних намистинок»50. Скриньки, як правило, належали жінкам. Пам'ятки образотворчого мистецтва й археологічні знахідки в еллінських містах Північного Причорномор'я свідчать, що такі речі, як дерев'яні скриньки, ларці часто використовували гречанки для зберігання прикрас 51 . Ю. Гребенников зазначив, що саме на землях Побужжя знайдено скриньки й інші предмети, які, можливо, потрапили до скіфського середовища завдяки гречанкам, які ставали дружинами скіфів. Поширенню змішаних шлюбів сприяла географія регіону, тобто близькість до Ольвії52.

Отже, прикраси зі скриньки, насамперед, пара сережок-човників. Прикраси цього типу вирізняє однакова будова: корпус, контури якого нагадують півмісяць, обернений «ріжками вверх», і дротяна дужка з відігнутим кінцем (рис. 10). Корпус зроблено з об'ємних половинок, значно розширених у нижній частині і звужених на кінцях. Виріб прикрашено орнаментами з гладеньких дротинок і зерні: з обох боків на деталях, повторюючи їх контури, напаяно дугоподібні «косички» - плетінки з двох тоненьких дротин, підкреслені зверху і знизу вузенькими дротяними смужками, та трикутниками дрібної зерні. Такі ж візерунки у місцях з'єднання половинок корпусу. Трикутники розміщені основою до дротяного обідка: вершиною вниз і вверх. Проміжок між ними відкриває гладеньку поверх-

46 Фармаковский Б.В. Три полихромные вазы в форме статуэток, найденные в Фанагории // Записки Российской Академии истории материальной культуры. Петроград, 1921. 45 с.

${ }^{47}$ Античные государства Северного Причерноморья / Археология СССР. Москва, 1984. С. 325. Табл. CXXXIV, 12

48 Бидзиля В.И., Полин С.В. Скифский царский курган Гайманова Могила. Киев: Издат. Дом «Скиф», 2012. Рис. 226, 4-5, кат. 315.

49 Ibid. C. 503.

50 Шапошникова О.Г., Балушкин Л.М., Гребенников Ю.С., Елисеев В.Ф., Клюшинцев В.Н., Ребедайло Г.Н., Товкайло Н.Т., Фоменко В.Н. Отчет о работе Николаевской экспедиции за 1982 г. // Науковий архів Інституту археології НАН України. Ф. експ. 1982/3. С. 73.

51 Цветаева Г.А. Мебель, бытовая утварь, отопление, освещение, предметы туалета, игрушки // Античные государства Северного Причерноморья. Москва: Наука, 1984. С. 228.

52 Гребенников Ю.С. Киммерийцы и скифы... С. 117. 
ню у вигляді ламаної лінії. На «ріжках» сережок - три дротяні кільця, верхнє та нижнє з насічками. Закінчення ріжок - п'ятипелюсткові розетки: кожна пелюстка з гладенької пластинки виділена дротинкою. Всередину розеток вставлені дротяні дужки (h - 41 мм, ширина - 22 і 28 мм). Форма і декор сережок пов'язані 3 культом плодючості53. Походження сережок цієї форми пов'язане з давнім мотивом «човна-місяця», поширеним у декоративному мистецтві Середземномор'я ще y II тис. до н.е. Найбільшого поширення сережки-човники набули у V-IV ст. до н.е. Прикраси з'явились як інокультурна модель, але стали невід'ємною частиною скіфського жіночого костюма, властивого племінній верхівці. Складні ювелірні техніки - зернь, візерунки з тоненької дротинки - все це свідчить про те, що авторство роботи належить представнику грецької «школи» - тобто сережки виготовили, мабуть, на Боспорі.

Ще одна сережка у скриньці - кільцеподібна з круглого у перетині дроту, розширеного у середній частині. Кінці звужені та близько підходять один до одного (рис. 11). Майстри виробляли бронзові, срібні та золоті кільця впродовж VI-IV ст. до н.е. Сережки-кільця з незімкненими кінцями носили як кліпси, тобто, закріплювали на мочці вуха. Схожі вироби мали серед інших прикрас представники верхівки ассирійського суспільства54. Деякі вчені наголошують, що у країнах Передньої Азії такі сережки (різних модифікацій), були характерною оздобою воїнів. Можливо, під час походів на Схід моду на масивні кільця запозичили і скіфи.

Поєднання у скриньці оздоб жіночих і притаманних чоловікові, було змістовно обумовленим. Можна припустити, що чоловіча сережка серед жіночих прикрас, $\epsilon$ свідченням якихось шлюбних ритуалів, які відбувались при похованні небіжчиків.

Золоті декоративні елементи, знайдені у похованнях на території Побужжя, дозволили скласти уявлення про деякі аспекти ювелірного мистецтва у регіоні. В художніх виробах проявились творчі пошуки місцевих майстрів. Йдеться про іконографію міфічних образів, зокрема, манеру стилізації зображень з алюзією на реальні видові ознаки тварин. Більшість витворів виконані грецькими майстрами, але відповідно до естетичних запитів скіфів, із врахуванням змістовного наповнення, символіки творів.

\section{REFERENCES}

Artamonov, M. I. (1966). Sokrovishcha skifskikh kurganov [Treasures of Scythian burial mounds]. Leningrad - Praga: Artia, Sovetskii khudozhnik [in Russian].

Bessonova, S.S. (1983). Religioznye predstavlenia skifov [Religious outlooks of the Scythians]. Kiev: Naukova dumka [in Russian].

Bessonova, S.S. (2007). Kalachikovidnye sergi i greko-varvarskie kontakty VII-IV vv. do n.e. [Kalatchshaped earrings and Greek-barbarian contacts in the $7^{\text {th }}-4^{\text {th }}$ centuries B.C.]. Bosporskie issledovania, XVI, 3-30 [in Russian].

Bidzilia, V.I. \& Polin, S.V. (2012). Srifskii tsarskii kurgan Gaimanova Mogila [Scythian royal mound of Gaimanova Mogila]. Kiev: Publ. House «Skif» [in Russian].

Dobroklonskii, M.V. \& Chubovaia, A.P. (Eds.). (1980). Istoria iskusstva zarubezhnykh stran [Art history of foreign countries]. Moskva: Izobrazitelnoe iskusstvo [in Russian].

Farmakovskii, B.V. (1921). Tri polikhromnye vazy v forme statuetok, naidennye v Fanagorii [Three

\footnotetext{
53 Бессонова С.С. Калачиковидные серьги и греко-варварские контакты в VII-IV вв. до н.э. // Боспорские исследования. Симферополь-Керчь, 2007. С. 22

54 Доброклонский М.В., Чубовая А.П. (ред.). История искусства зарубежных стран. Москва: Изобразительное искусство, 1980. С. 179, 180, рис. 177; 18
} 
polychrome figurine-shaped vases founded in Phanagoria]. In Zapiski Rossiiskoi Akademii istorii materialnoi kultury. Petrograd [in Russian].

Grebennikov, Yu.S. (2008). Kimmeriitsy i skify Stepnogo Pobuzhia (IX-III vv. do n.e.) [Cimmerians and Scythians of the Steppe Bug Region (IX-III centuries BC)]. Nikolaev [in Russian].

Grebennikov, Yu.S. (2008). Skifska model «administratyvnoho» ustroiu Stepovoho Pobuzhia v V-IV st. do n.e. [Scythian model of the «administrative» system of the Steppe Pobuzhye in the V-IV centuries B.C.]. Eminak, 3, 25-29 [in Ukrainian].

Irmscher, J. (Hg.) (1979). Lexikon der Antike. Leipzig: VEB Bibliographisches Institut.

Kantorovich, A.R. (2015). Obrazy sinkreticheskikh sushchestv v vostochnoevropeiskom skifskom zverinom stile: klassifikatsiya, tipologiya, khronologiya, ikonograficheskaya dinamica [Syncretic images of creatures in the Eastern Scythian animal style: classification, typology, chronology, iconography dynamics]. Istoricheskie issledovania, 3, 113-218 [in Russian].

Klochko, L.S. (1982). Novye materialy k rekonstruktsii skifskikh golovnykh uborov [New materials for the reconstruction of Scythian headdresses]. In Drevnosti Stepnoi Skfii. Kyiv: Naukova dumka, pp. 118-130 [in Russian].

Klochko, L.S. (2013). Tipy dekorativnykh elementov v oformlenii golovnykh uborov skifianok [Types of decorative elements in the design of Scythian hats]. Tiragetia, VII (XXII), I, 19-28 [in Russian].

Klochko, L.S. (1984). Verkhnii plechovyi odiah skifiv [Scythian upper shoulder clothing]. Arkheologia, 47, 57-68 [in Ukrainian].

Klochko, L.S. (2000). Zoomorfni obrazy v dekori srifskikh holovnych uboriv V-IV st. do n.e. [Zoomorphic images in the decor of Scythian hats V-IV centuries B.C.]. Proceedings of the Conference: Muzeini chytannia. Kyiv, pp. 23-98 [in Ukrainian].

Klochko, L.S. \& Grebennikov, Yu.S. (1982). Skifskii kalaf IV v. do n.e. [Scythian Calaf of IV century BC]. In Materialy po khronologii arkheologicheskikh pamiatnikov Ukrainy. Kyiv: Naukova dumka, pp. 86-96 [in Russian].

Klochko, L.S. \& Ivanenko, A.S. (2017). Polos, kalaf, modii (rekonstruktsii za azhurnymy prykrasamy zi skifskykh pokhovan) [Stripes, calaf, modii (reconstruction by delicate ornaments from Scythian burials]. Pratsi tsentru pamiatkoznavstva, 32, 41-52 [in Ukrainian].

Klochko, L.S., Pidvysotska, O.P., Starchenko, O.V. \& etc. (2004). Muzei istorychnykh koshtovnostei Ukrainy: Albom [Museum of Historical Treasures of Ukraine: Album]. Kyiv: Mystetstvo [in Ukrainian].

Klochko, L. S., Vasina Z. O. (2002). Rekonstruktsia holovnykh uboriv za dekoratyvnymy elementamy iz pokhovan skifianok (versii zahalnoi klasyfirftsii [Reconstruction of headdresses according to decorative elements from Scythian burials (versions of the general classification)]. Proceedings of the Conference: Muzeini chytannia. Kyiv, pp. 32-43 [in Ukrainian].

Koshelenko, G.A., Kruglikova, I.T. \& Dolgorukov, V.S. (Eds.) (1984). Antichnye gosudarstva Severnogo Prichernomoria [Ancient states of the Northern Black Sea Region]. Moskva: Nauka [in Russian].

Leskov, O.M. (1974). Skarby kurhaniv Khersonshchyny [Treasures of mounds of Kherson Region]. Kyiv: Mystetstvo [in Ukrainian].

Miroshyna, T.V. (1981). Nekotorye tipy skifskikh zhenskikh gollovnykh uborov IV-III vv. do n.e. [Some types of Scythian women's headdresses of the $4^{\text {th }}-3^{\text {rd }}$ centuries BC]. Sovetskaia arkheologiia, 4, 4669 [in Russian].

Petrenko, V.G. (1978). Ukrashenia Skifii VII-III vv. do n.e. [Jewelery Scythia VII-III century BC]. Moskva: Nauka [in Russian].

Polidovych, Yu.B. (2015). Obpazy fantastichtskikh zhivotnykh v iskusstve narodov skifskogo mira [Images of fantastic animals in the art of the peoples of the Scythian world]. Donetskyi arkheolohichnyi zbirnyk, 19, 85-142 [in Russian].

Polidovych, Yu.B. \& Shamina, T.Yu. (2018). Zobrazhennia skifskoho drakona v kolektsii Muzeiu istorychnykh koshtovnostei Ukrainy [The image of the Scythian dragon in the collection of the Museum of Ukraine Historical Treasures]. Proceedings of the Conference: Muzeini chytannia. Kyiv, pp. 69-76 [in Ukrainian].

Polin, S.V. (2014). Skifskii Zolotobalkovskii kurgannyi mogilnyk V-IVvv. do n.e. na Khersonshchine [Scythian Zolotobalkovsky burial mound of the $5^{\text {th }}-4^{\text {th }}$ centuries BC in the Kherson Region]. Kyiv [in Russian].

Polos'mak, N. \& Barkova, L. (2005). Kostium i tekstil pazyryktsev Altaia (IV-III vv. do n.e.) [The costume and textiles of the Altai Pazyryk people (IV-III centuries BC)]. Novosibirsk: Infolio [in Russian].

Raevskii, D.S. (1977). Ocherki ideologii skifo-sakskikh plemen [Essays on ideology Scythian-Saka tribes]. Moskva: Nauka [in Russian]. 
Rostovtsev, M.I. \& Stepanov, P.K. (1918). Ellino-skifskii golovnoi ubor [Hellenic-Scythian headdress]. Izvestiia arkheologicheskoi komissii, 63, 69-100 [in Russian].

Savostina, E.A. (1996). «Zmeenogaia boginia» - «prorastaiushchaia deva» (dvukhstoronnii antroterii iz Pantikapeia [«Serpentine goddess» - «sprouting maiden» (double-sided anthropomorphic acrotherium from Panticapaeum)]. Istoriko-arkheologicheskii al'manakh, 2, 76-83 [in Russian].

Shaposhnikova, O.G., Balushkin, L.M., Grebennikov, Yu.S. \& etc. (1984). Otchet o rabote Nikolaevskoi ekspeditsii za 1984 god. Chast II. Raboty Yavkinskogo otriada [Report on the work of the Nikolaev expedition in 1984. Part II. Works of the Yavkino's detachment]. The Scientific Archive of Institute Archeology NAS of Ukraine, 9 [in Russian].

Shaposhnikova, O.G., Balushkin, L.M., Grebennikov, Yu.S. \& etc. (1986). Otchet o rabote Nikolaevskoi ekspeditsii za 1986 god [Report on the work of the Nikolaev new-building expedition in 1986]. The Scientific Archive of Institute Archeology NAS of Ukraine, 18 [in Russian].

Shaposhnikova, O.G., Balushkin, L.M., Grebennikov, Yu.S., Eliseev, V.F., Kliushintsev, V.N., Rebedailo, G.N., Tovkailo, H.T. \& Fomenko, V.N. (1982). Otchet o rabote Nikolaevskoi ekspeditsii za $1982 \mathrm{~g}$. [Report on the work of the Nikolaev expedition in 1982]. The Scientific Archive of Institute Archeology NAS of Ukraine, 3 [in Russian].

Terenozhkin, A.I., Ilinskaia, V.A., Chernenko, E.V. \& Mozolevskii, B.N. (1973). Skifskie kurgany Nikopolshchiny [Scythian burial mounds of Nikopol Region]. In Skifskie drevnosti. Kyiv: Naukova dumka, pp. 113-187 [in Russian].

Tsvetaeva, G.A. (1984). Mebel, bytovaia utvar, otoplenie, osveshchenie, predmety tualeta, igrushki [Furniture, household utensils, heating, lighting, toilet items, toys]. In Antichnye gosudarstva Severnogo Prichernomoria. Moskva: Nauka, pp. 227-229 [in Russian].

Vertienko, G.V. (2010). Zobrazhennia skifskoi tanatologichnoi mifologemy na sakhnivskii plastyni [Image of Scythian thanatological mythology on sahnivskiy plate]. Skhidnyi svit, 3, 59-73 [in Ukrainian].

Vynogrodska, Ya.O. (2000). Do interpretatsii zobrazhen na plativkakh skifskogo arkhaichnogo golovnogo uboru [To the interpretation of images on plates of the Scythian archaic headdress]. Proceedings of the Conference: Muzeini chytannia. Kyiv, pp. 17-23 [in Ukrainian].

Yakovenko, E.V. (1991). Pro ckifski veretena [About Scythian spindles]. In Zoloto stepu. Arkheologia Ukrainy. Shlezvig, pp. 112-114 [in Ukrainian].

\section{Liubov Klochko}

(National Museum of Ukraine History, Kyiv, Ukraine)

e-mail: liubaklochko@ukr.net

ORCID: https://orcid.org/0000-0003-3496-6340

\section{Decorative Elements of Steppe Buh Region Population Clothing}

Steppe Buh region is an area in the basins of the rivers Southern Buh and Inhulets, which, according to the archeological materials, during the $5^{\text {th }}-3^{\text {rd }}$ centuries BCE supposedly was a separate administrative region of Scythia. The specific social life conditions formed there because of the proximity of Olbia, family and tribal ties, and peculiarities of housekeeping. Such conclusions could be made as a result of studying the funeral implements from the barrows of the region. Especially informative are the artifacts of various categories originating from unlooted burials. In one of them (barrow 21 near the village of Kamianka) the decorative elements of the costume of a woman, who supposedly was a priestess of the Great Goddess, were found. First of all, this is indicated by the appliqued ornaments on her headdress named 'modiia'. Their analysis uncovered the originality of iconography and semantics of images. Of particular interest are the so-called griffins with goat heads. The decorations of the young man's costume, whose burial was studied in barrow 9 near the village of Pisky, also attract close attention. The decorative elements of his clothing, such as gold appliqued ornaments on clothes, a hryvna, and a bracelet, are typical for the representative of the top of society. A peculiar feature is a golden hryvnia, having the points in the form of stylized images of the fantastic bird's head (griffin's head?).

The earrings found in a coffret in one of the graves (barrow 2, burial 1 near the village of 
Taborivka), confirm the assumption of mixed marriages: Greek women became the wives of the Scythians.

In the $5^{\text {th }}$ century BCE the Hellenic ornaments, decorative elements on the headdresses and clothing came into vogue among the elite of the Scythian population. It is proved, in particular, by the items of jewelry art, where Greek motifs dominate. They probably got a new interpretation in the minds of the Scythian population permeating into the material and spiritual spheres of its life. But many works of art were made mainly in the workshops of Greek jewelers, possibly in Bosporus, or in Olbia. In general, decorative art in the Buh region developed in line with the Greek and Scythian traditions.

Keywords: mythical images, semantics of removable jewelry, Scythian headdresses 


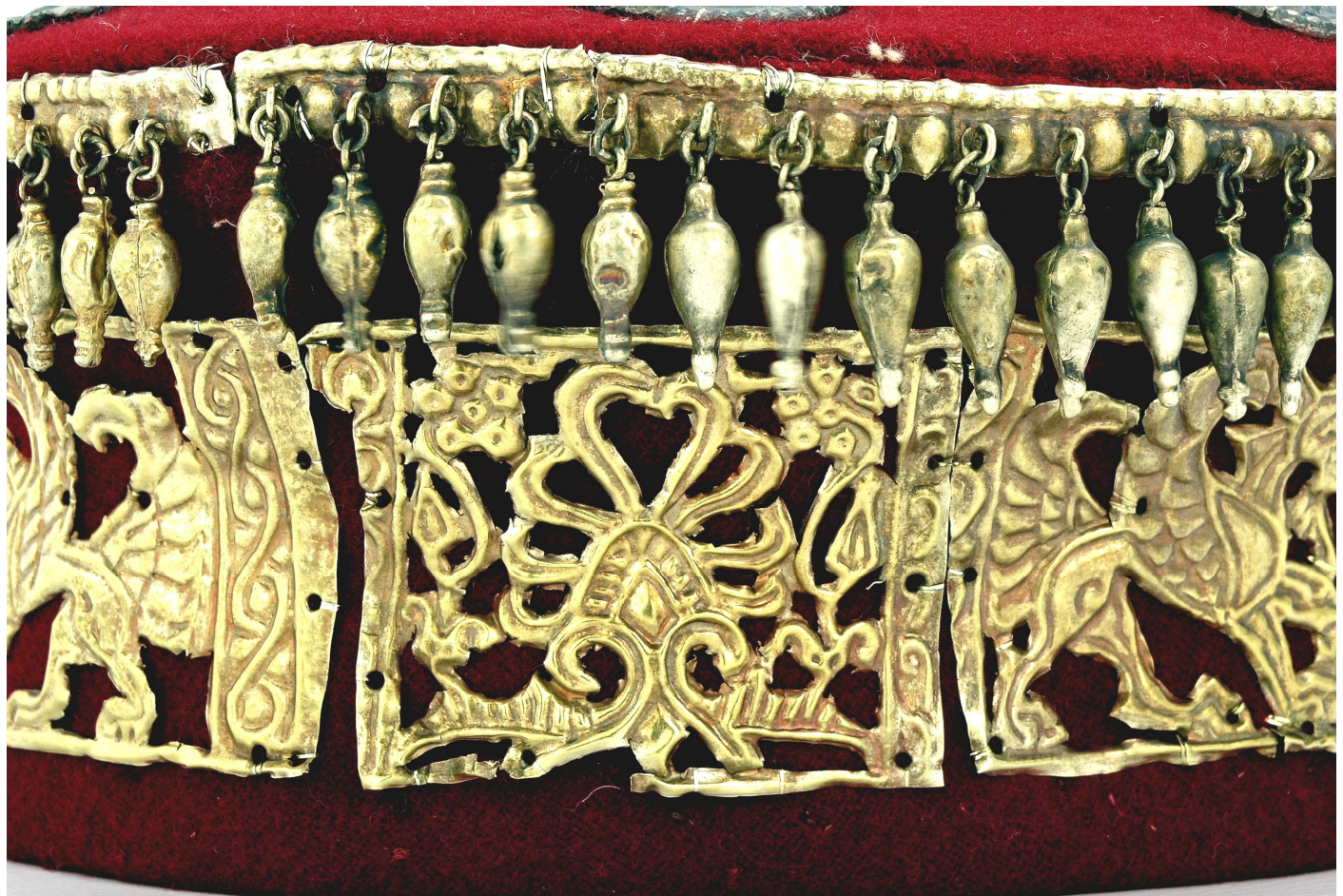

Рис. 1.1. Зображення пальметки.

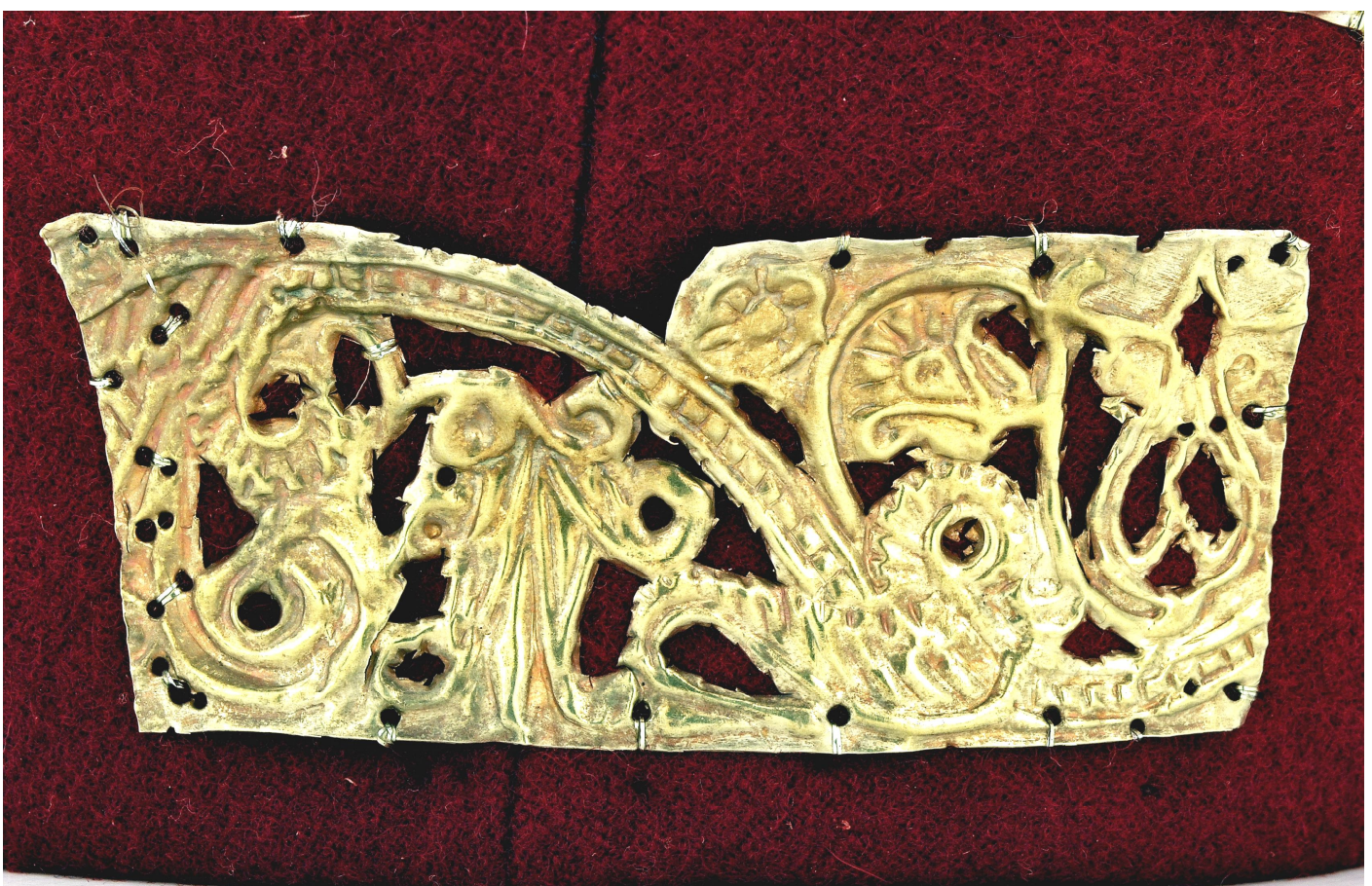

Рис. 1.2. Фрагмент візерунка 


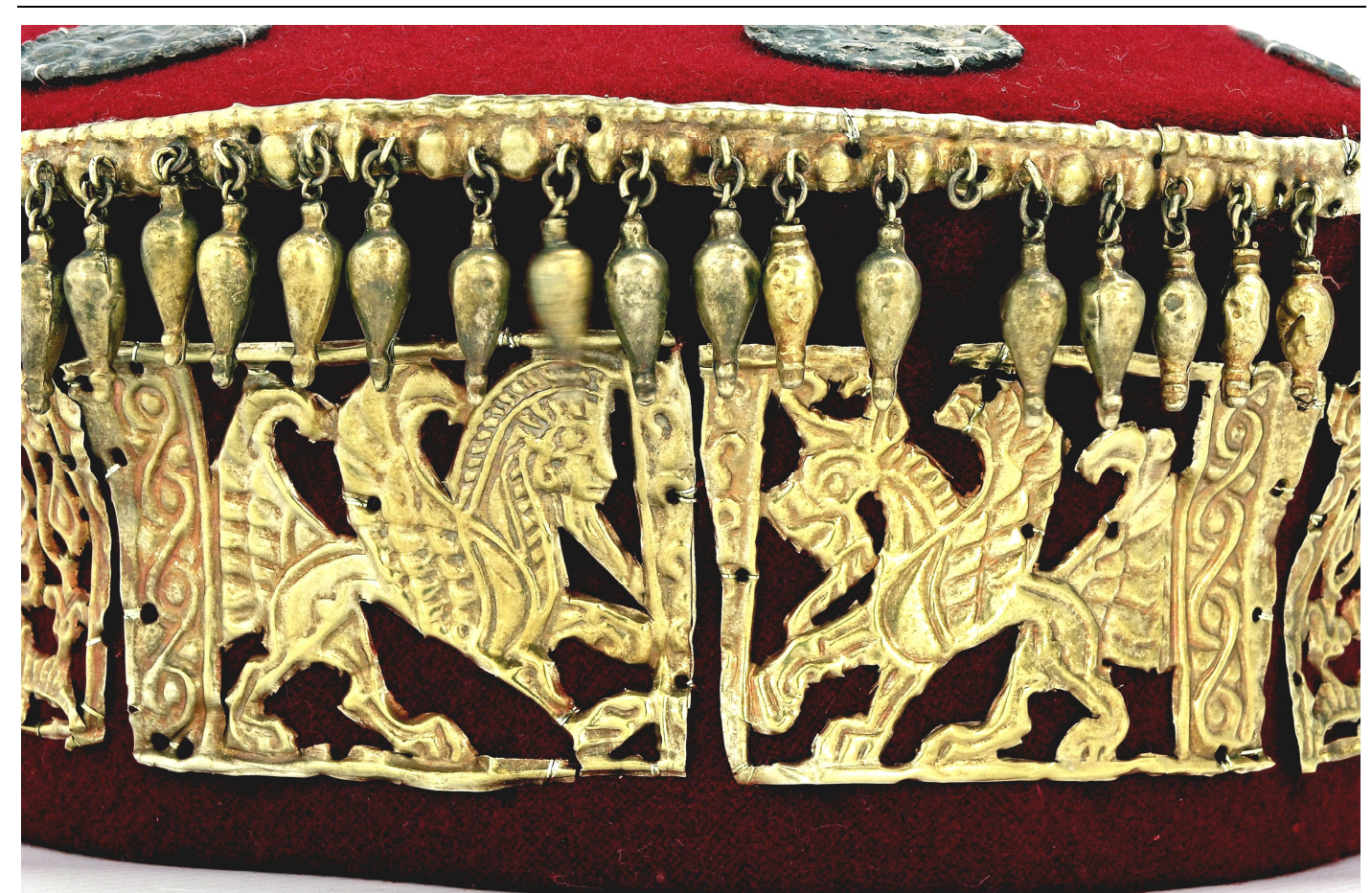

Рис. 1.3.а. Образ грифона, оберненого вліво;

Рис. 1.3б. Зображення міфічної істоти з головою козла (в профіль вправо)

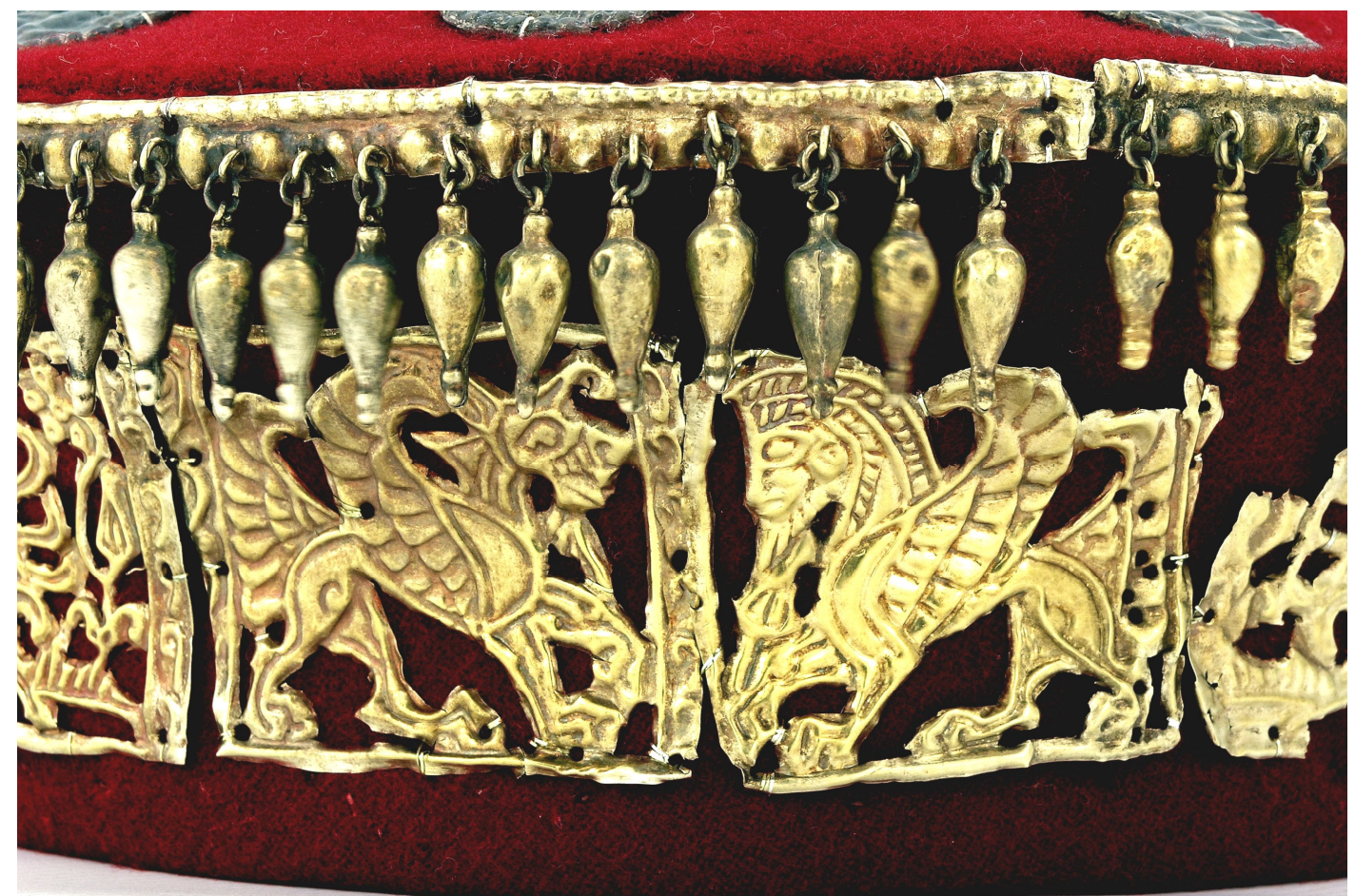

Рис. 1.4.а. Зображення грифона в профіль вправо;

Рис. 1.4б. Образ монстра з головою козла (в профіль вліво) 


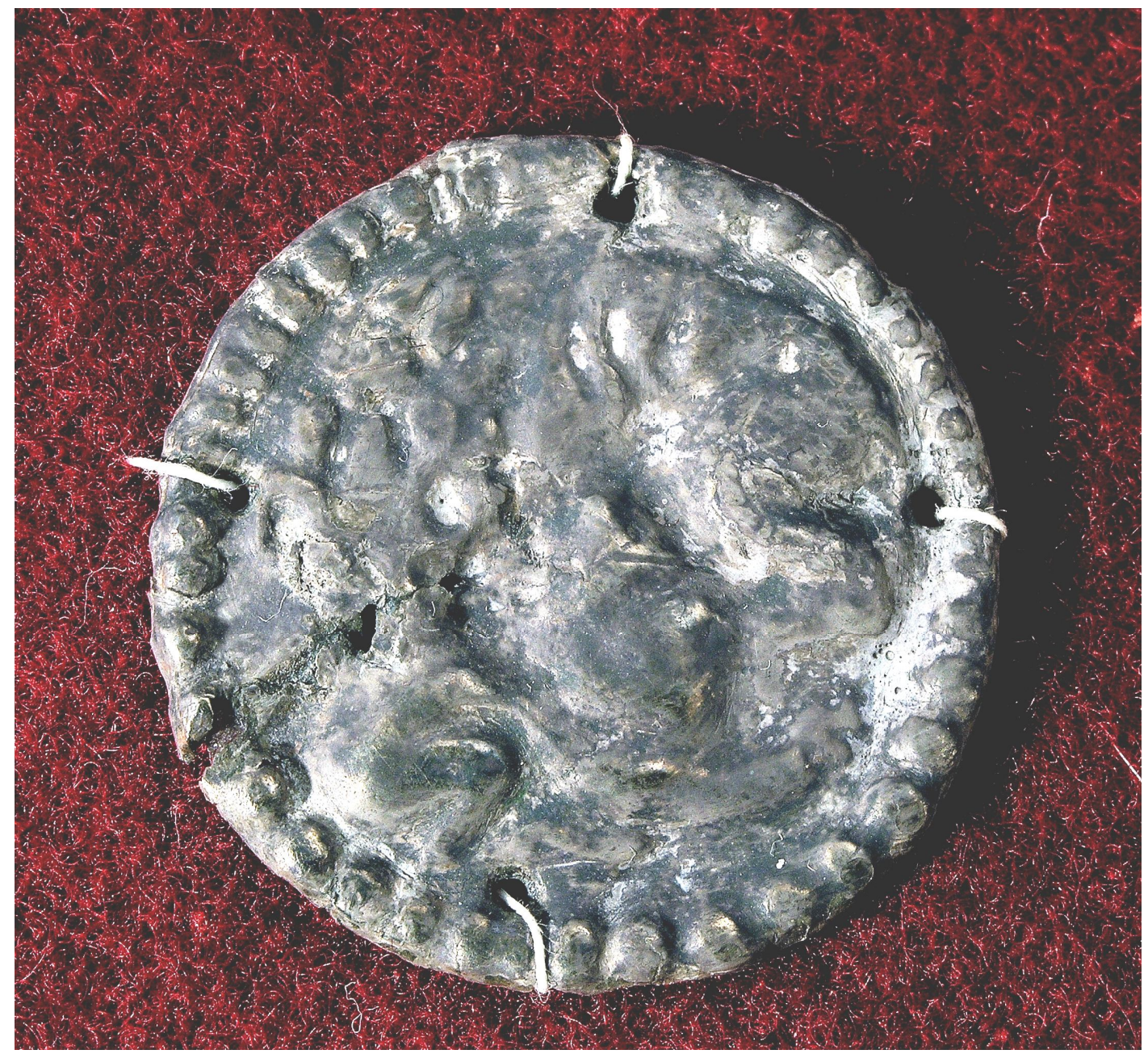

Рис. 1.5. Срібна пластинка із зображенням сцени шматування 


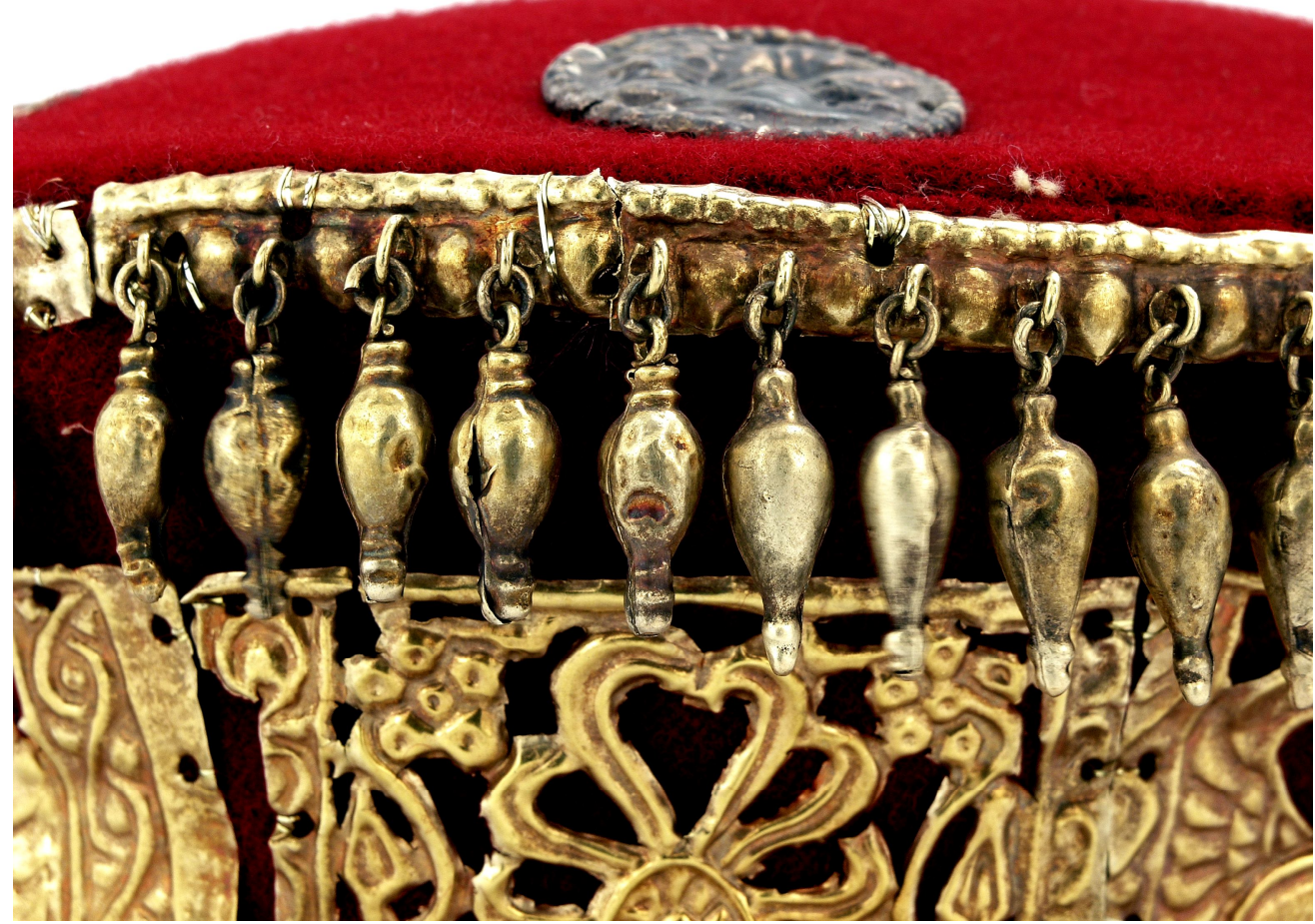

Рис. 1.6. Обідки з підвісками

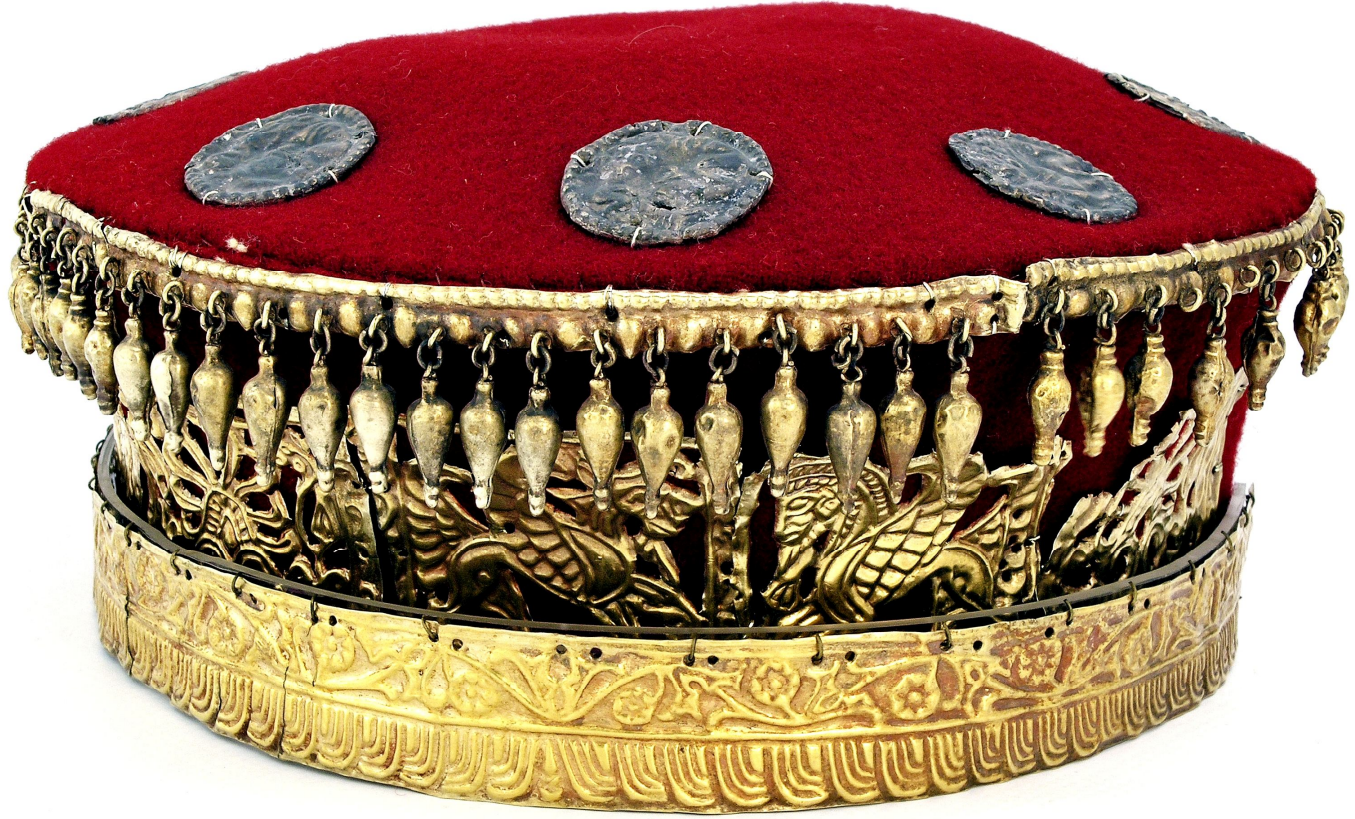

Рис. 1.7. Реконструкція головних уборів: модія з налобною стрічкою

Рис. 1. Золоті прикраси головного убору модія з поховання № 2 кургану 21 поблизу с. Кам'янка. Ажурні пластини (АЗС3232 - 3234). 


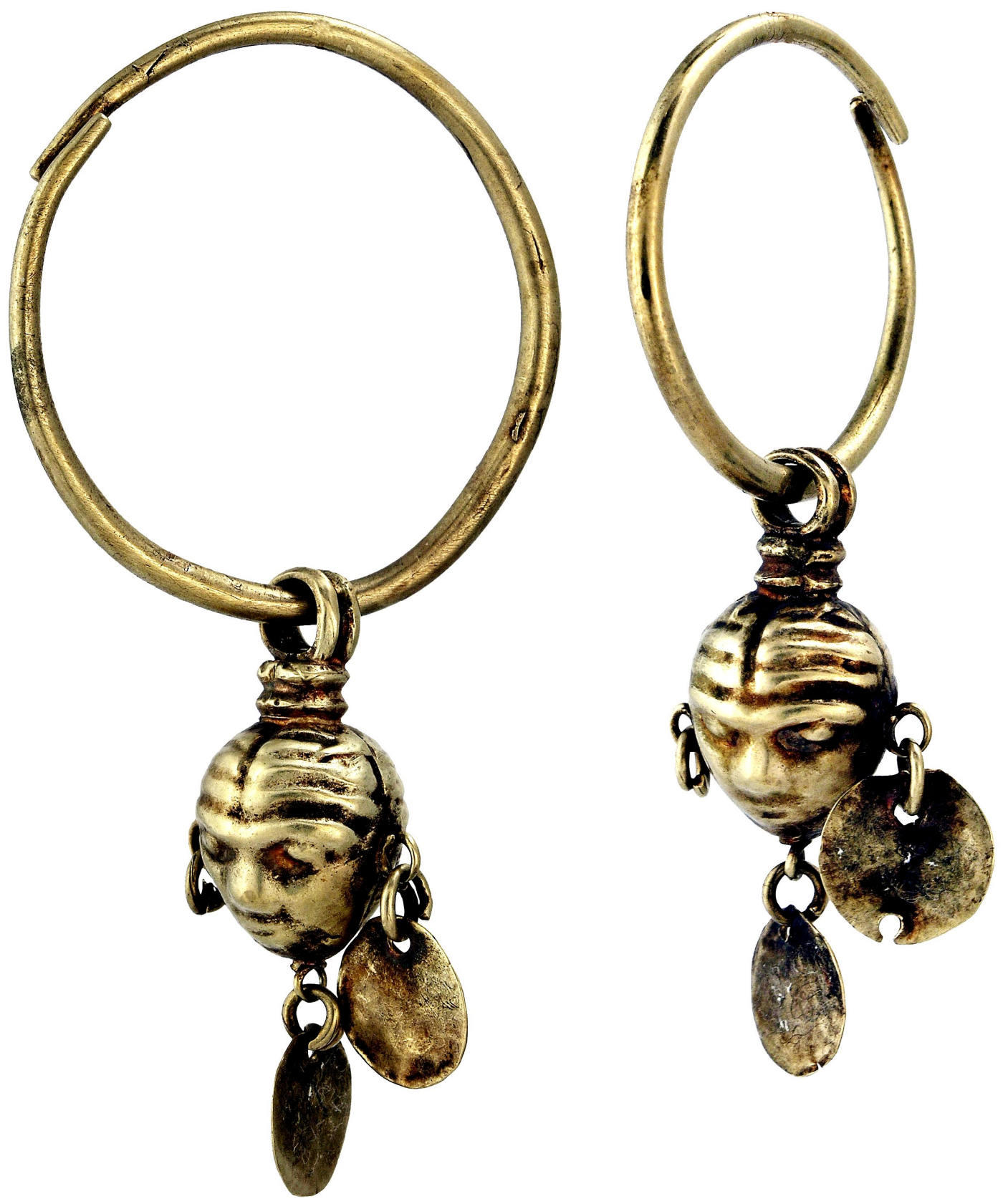

Рис. 2. Сережки з кургану 21 (поховання 2)

поблизу с. Кам'янка (Миколаївська обл.) (АЗС 3235) 


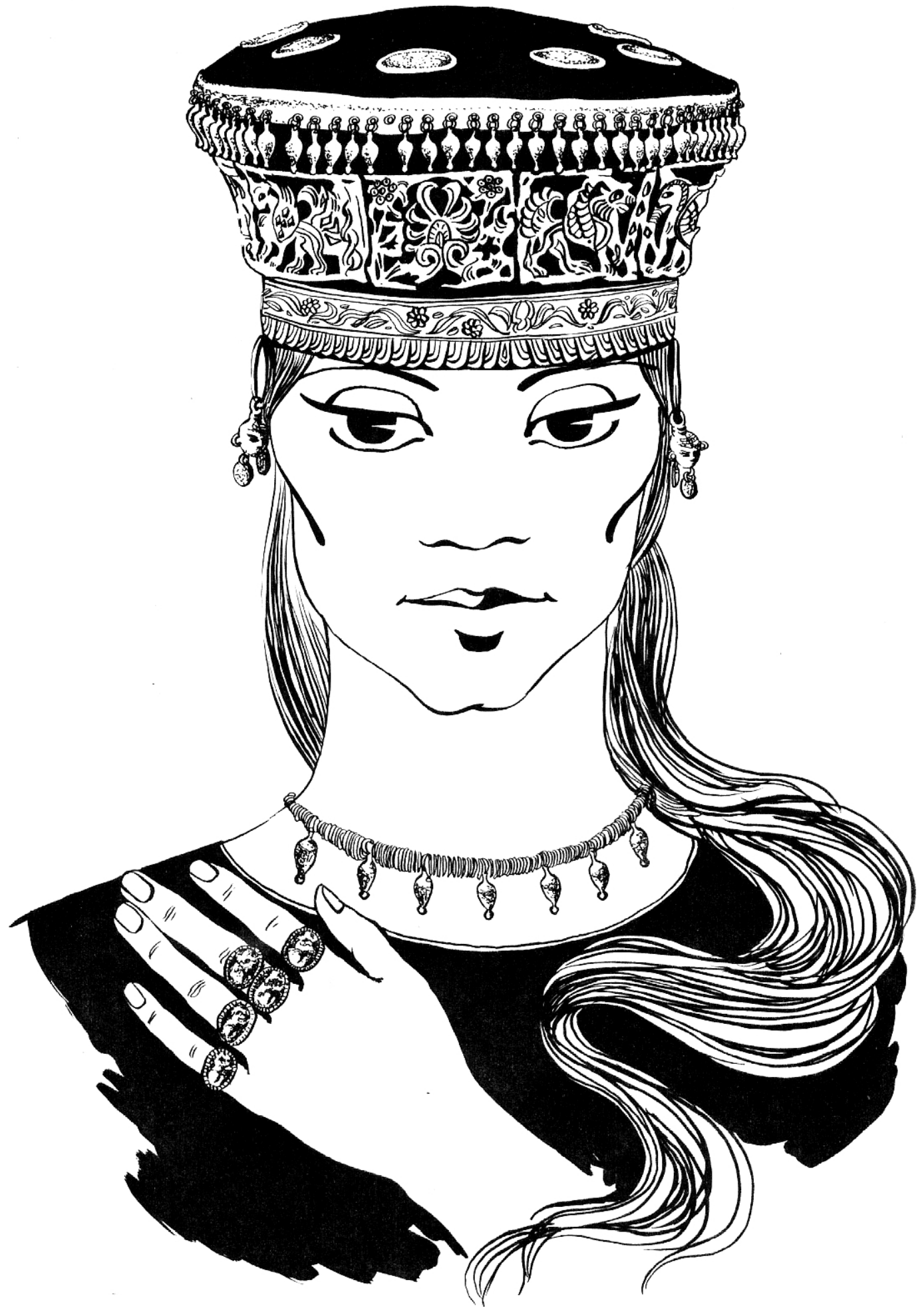

Рис. 3. Реконструкція костюмного комплексу з кургану 21 (поховання 2) поблизу с. Кам'янка (Миколаївська обл.) 


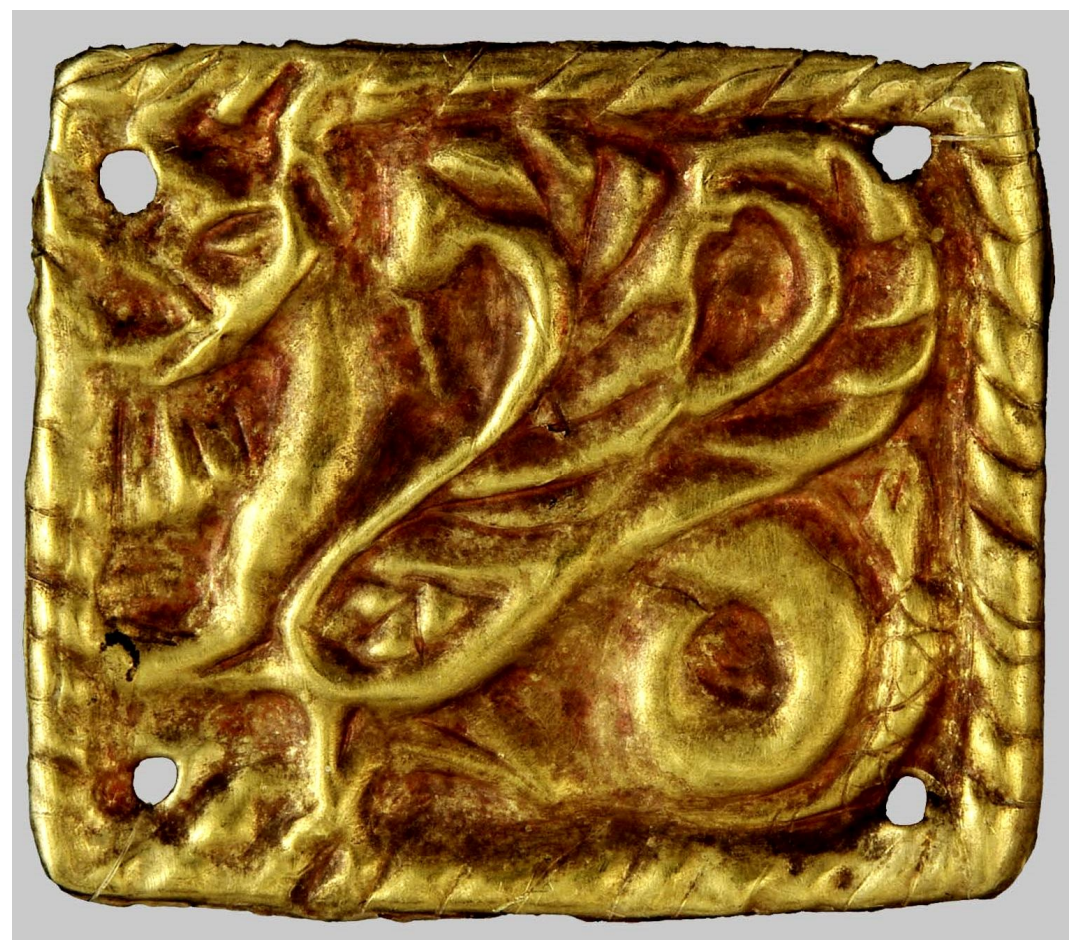

Рис. 4. Пластинка із зображенням дракона (курган 9, поховання 1 поблизу с. Піски (Миколаївська обл.) (АЗС 2724)
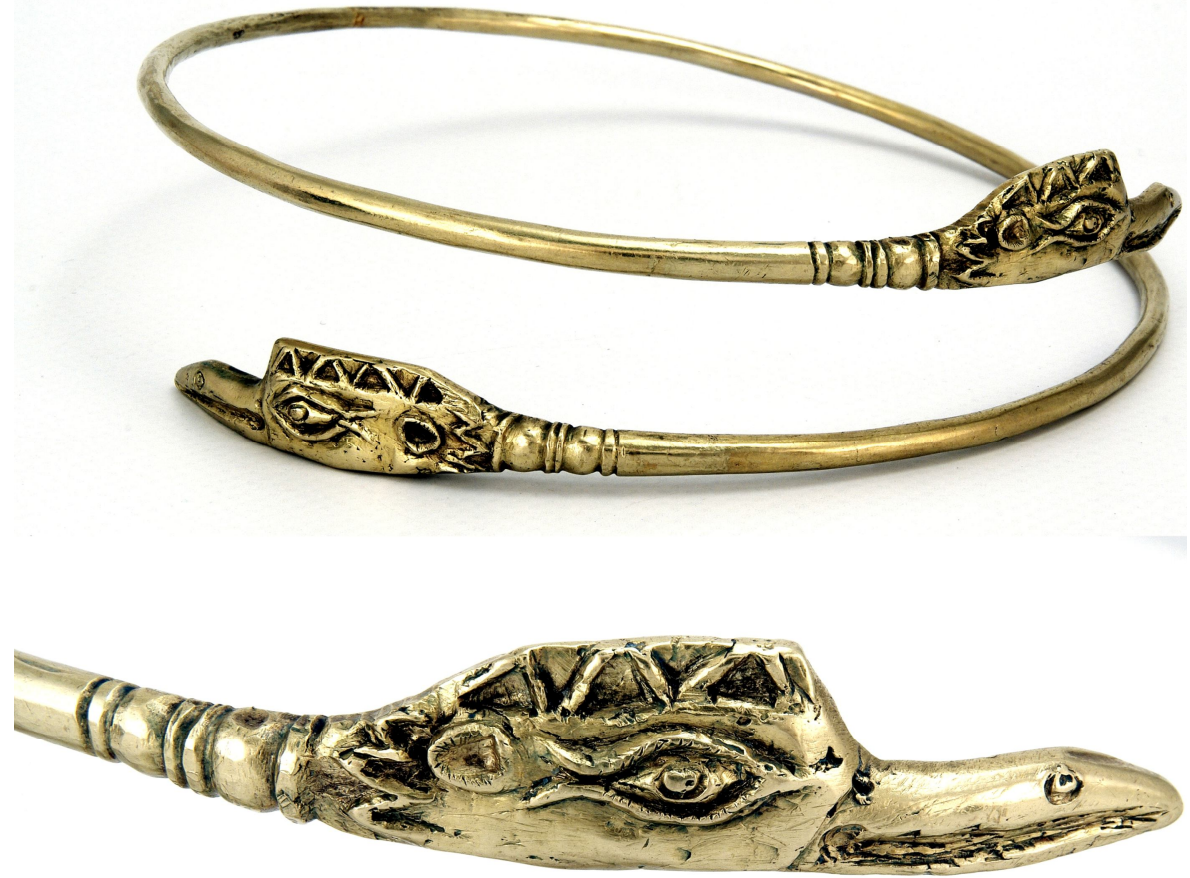

Рис. 5. Гривна із зоомофними закінченнями (АЗС 2727) 


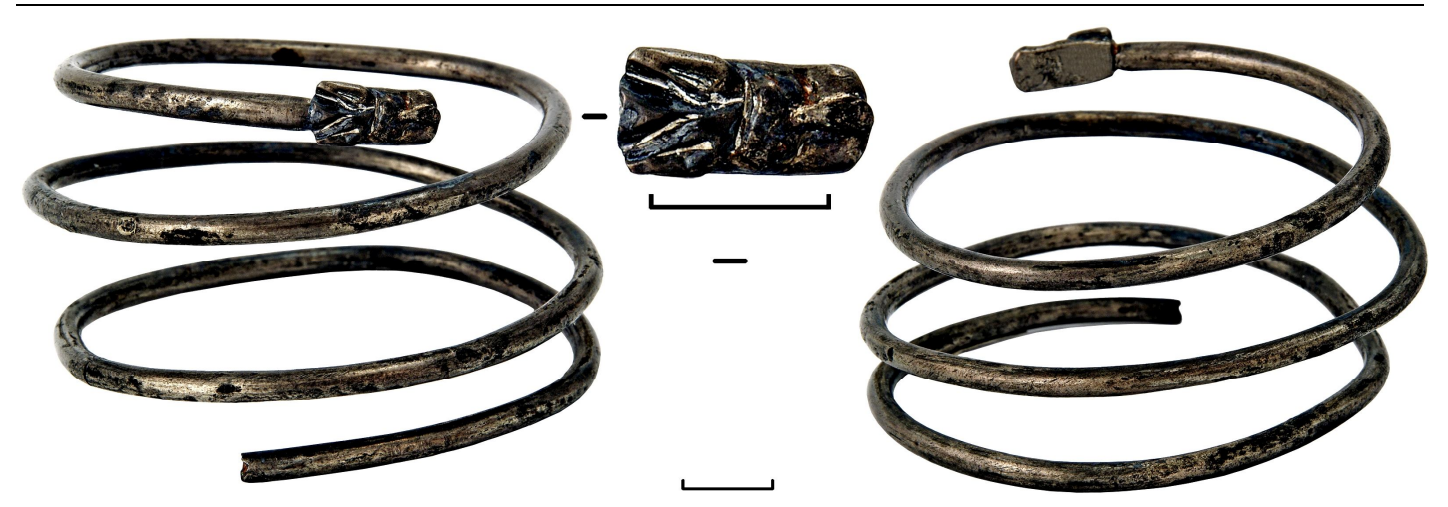

Рис. 6. Спіральний срібний браслет (АЗС 2726)

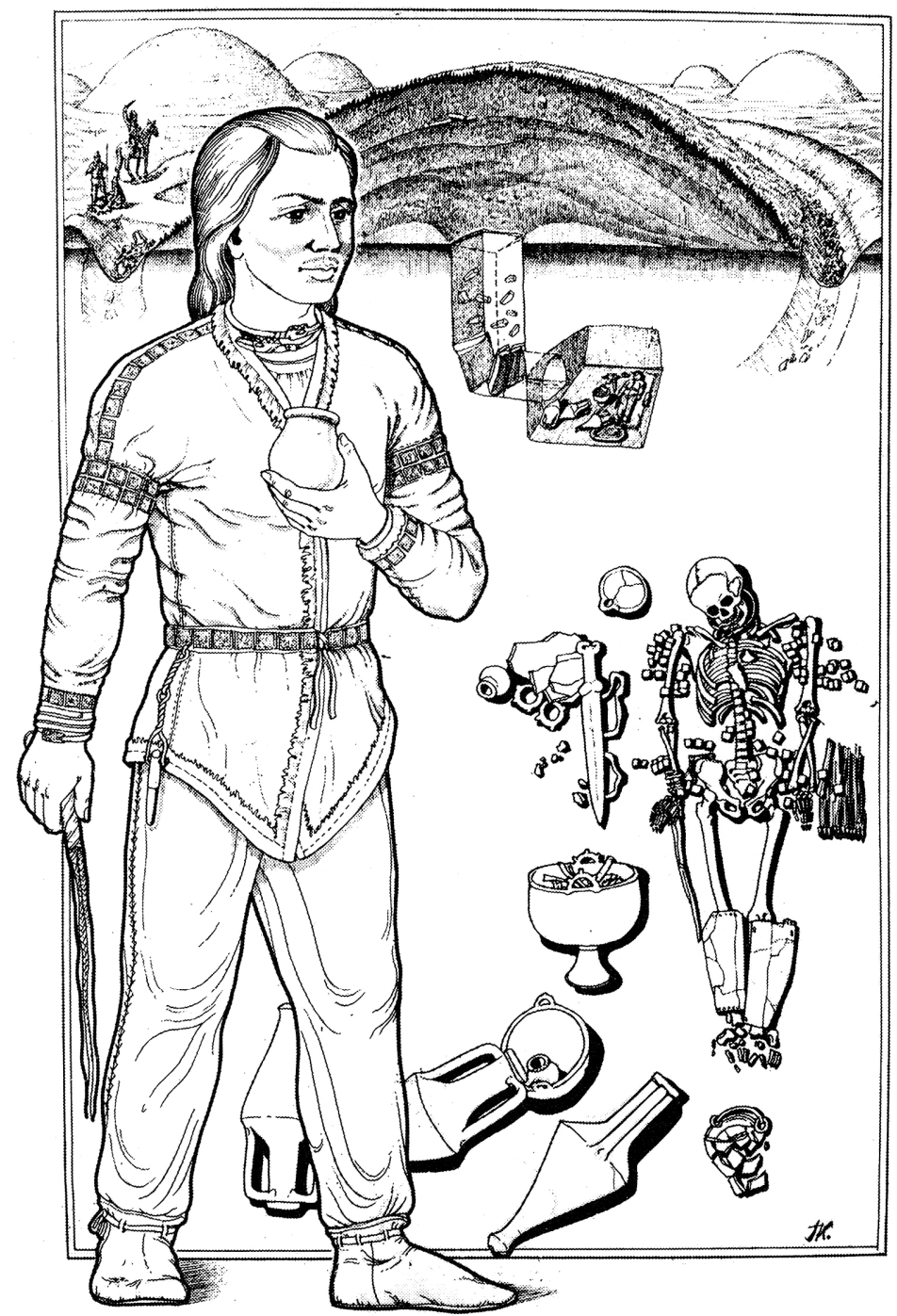

Рис. 7. Реконструкція костюма скіфа (курган 9, поховання 1 поблизу с. Піски (Миколаївська обл.). 


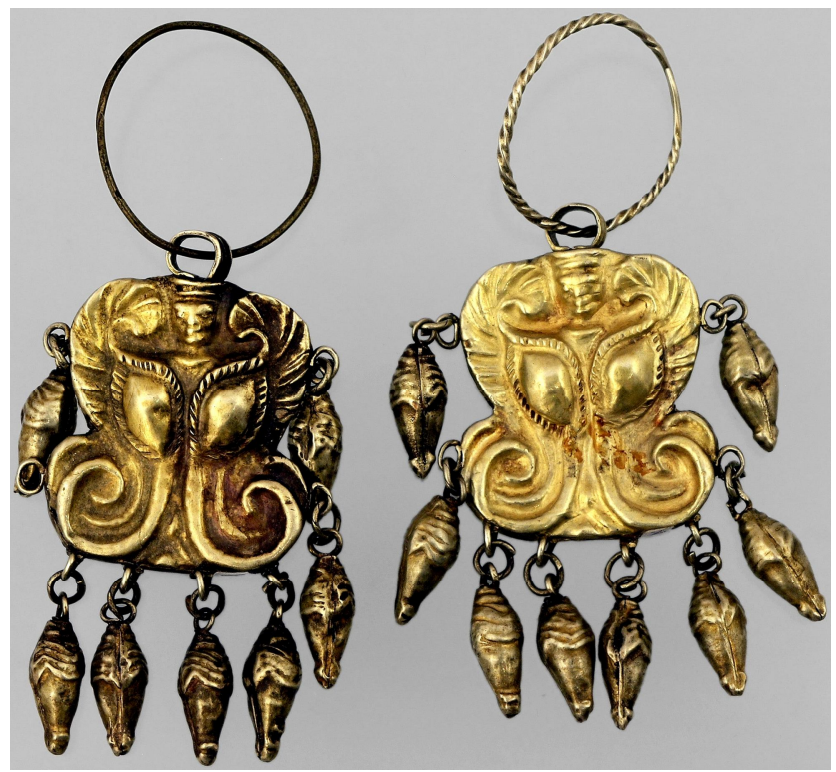

Рис. 8. Сережки із зображенням крилатого божества (АЗС 3839; курган 6, поховання 1 поблизу с. Мар'янівка Миколаївської обл.).

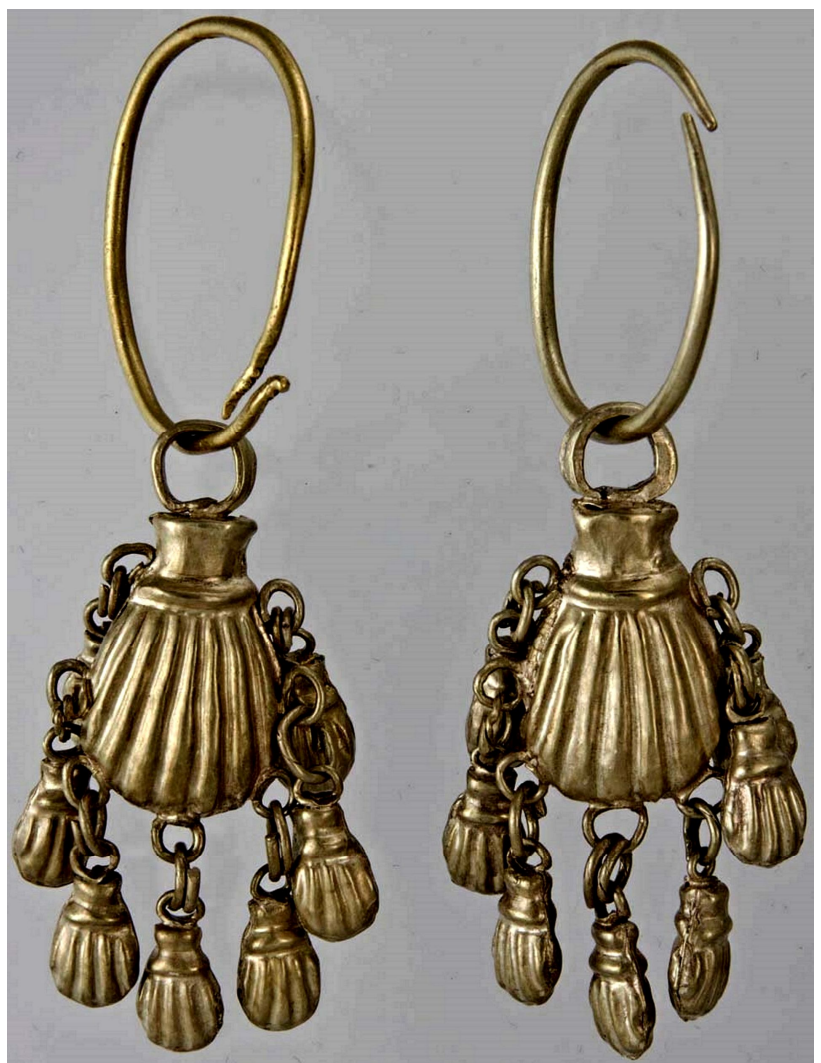

Рис. 9. Сережки з підвісками у вигляді мушель; курган 29 (поховання 1) поблизу с. Пришиб (АЗС 3567) 

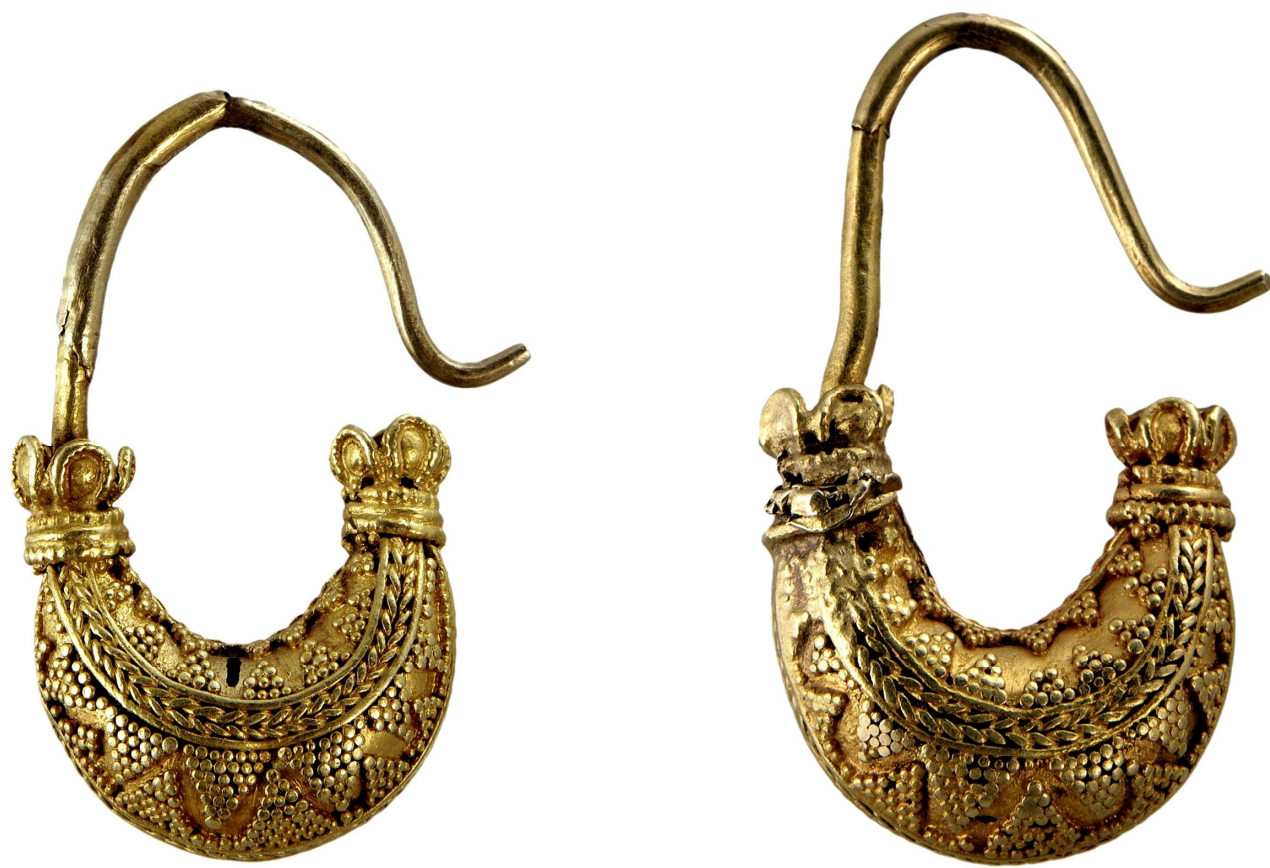

Рис. 10. Сережки - човники з поховання жінки в кургані № 2 (поховання 1) поблизу с. Таборівка (Миколаївська обл.). (АЗС 3477)

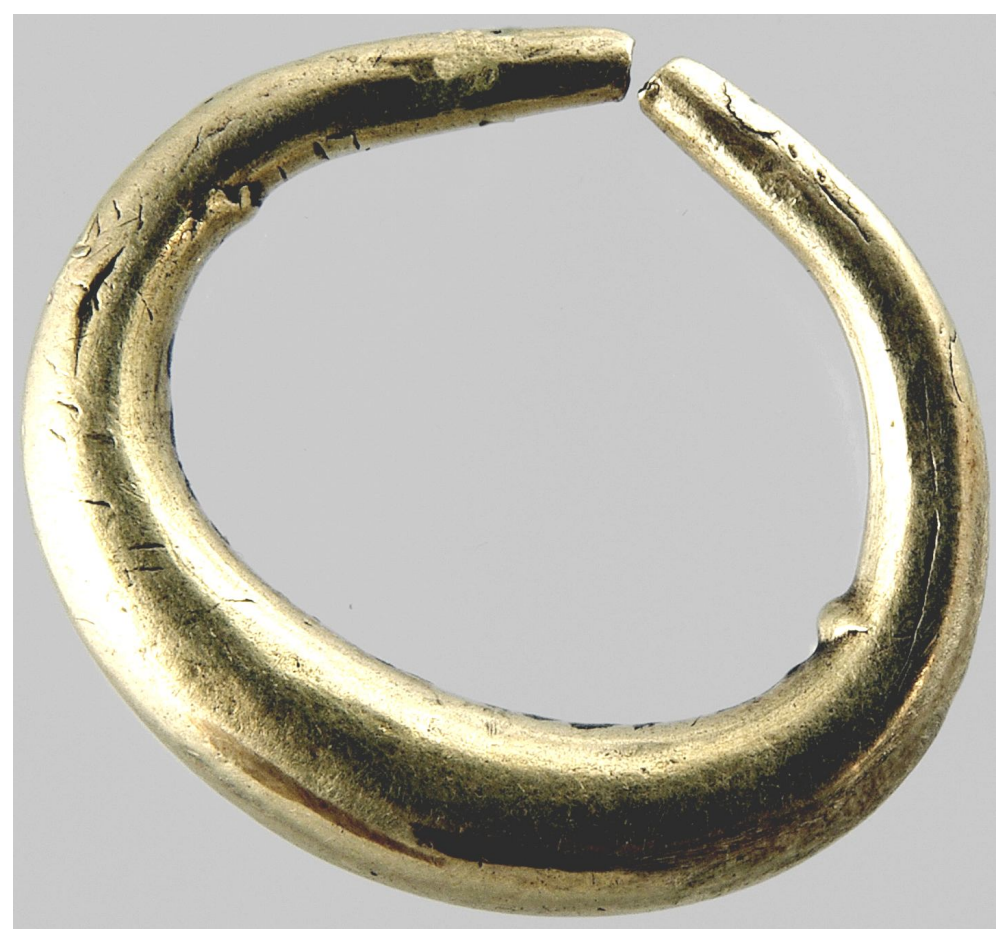

Рис. 11. Кільцеподібна сережка з поховання жінки в кургані № 2 (поховання 1) поблизу с. Таборівка (Миколаївська обл.). (АЗС 3478) 